\title{
The Battle over Self-Insured Health Plans, or "One Good Loophole Deserves Another"
}

\author{
Russell Korobkin, J.D.*
}

Enacted in 1974, the federal Employee Retirement Income Security Act (ERISA) ${ }^{1}$ has been a major roadblock to advocates of increased regulation of health insurance benefits in the era of "managed care." Originally drafted as a pension law, ERISA, as enacted, applies to all fringe benefits provided by private employers to their employees. The statute shields benefit plans, including health insurance, from state regulation in two ways. First, ERISA's "preemption" clause prohibits state laws that "relate to" employee benefit plans. ${ }^{2}$ Second, although ERISA's "savings clause" exempts state laws that "regulate insurance" from the statute's preemptive force, ${ }^{3}$ this exception is in turn limited by the "deemer clause," which prevents state insurance regulations from reaching employer health care benefits plans (EHBPs) that are self-insured, ${ }^{4}$ as opposed to those that purchase insurance coverage from a third party. Put another way, ERISA obstructs state regulation on two levels: The statute partially shields all EHBPs from state regulation, and self-insured EHBPs enjoy an enhanced level of protection.

A large chorus of critics has lodged two different types of complaints about ERISA. On one hand, critics contend that managed care arrangements threaten consumer health and that the expansion of these insurance systems requires the government to police health insurers more closely. ERISA preemption impedes possible state regulatory efforts. ${ }^{5}$ On

* Professor of Law, UCLA and Faculty Associate, UCLA Center for Health Policy Research. Comments on earlier drafts from Tom Baker, John Day, Mark Hall, Peter Jacobson, John Jacobi, Bill Sage, Rich Saver, and workshop participants at the UCLA Center for Health Policy Research are gratefully acknowledged. Invaluable research assistance was provided by Heather Richardson.

1. Employee Retirement Income Security Act of 1974, Pub. L. No. 93-406, 88 Stat. 829 (codified as amended at 29 U.S.C. $\$ \S 1001-1461(2000)$ ).

2. 29 U.S.C. $\$ 1144(2000)$.

3. $I d . \S 1144(\mathrm{~b})(2)(\mathrm{A})$.

4. Id. $\$ 1144(\mathrm{~b})(2)(\mathrm{B})$.

5. See, e.g., Robert Covington, Amending ERISA's Preemption Scheme, 8 KAN. J.L. \& PuB. 
the other hand, to the extent that ERISA's savings clause enables state regulation of managed care to avoid preemption, critics complain that ERISA creates an inequitable two-tiered regulatory system, in which employees in "insured" plans receive protections of state law denied to employees in "self-insured" plans.

In the past three terms, two important United States Supreme Court decisions, Rush Prudential HMO v. Moran ${ }^{7}$ and Kentucky Ass'n of Health Plans $v$. Miller, ${ }^{8}$ expanded the scope of ERISA's savings clause, giving states greater latitude to regulate managed care. A third decision, Aetna Health Inc. $v$. Davila, ${ }^{9}$ added to the significance of Rush Prudential. At the same time, the Court did not change its interpretation of the deemer clause: In fact, there have been no Supreme Court rulings dealing with the deemer clause since $1990 .^{10}$ The result is that, as the scope of ERISA preemption has contracted, the gap in regulatory protections enjoyed by employees in insured and self-insured plans has expanded. An employer's decision about whether to purchase third-party insurance or to self-insure its employees' health care expenses has taken on increasing significance, creating two competing incentives. Employers who wish to avoid the costs associated with state regulation have a greater incentive to establish selfinsured EHBPs, and the supporters of regulation have more incentive than ever to fight self-insurance.

A change in federal law would moot this issue. Congress could amend ERISA to provide equal legal treatment for employees in insured and selfinsured EHBPs, or the courts could reinterpret the savings and deemer

POL'Y 1 (1999); Mark A. Edwards, Plan Protections for ERISA Self-Insured Employee Welfare Benefit Plan Participants: New Possibilities for State Action in the Event of Plan Failure, 1997 WIS. L. REV. 351; Margaret G. Farrell, ERISA and Managed Care: The Law Abhors a Vacuum, $29 \mathrm{~J}$. Health L. 268 (1996); James Saya, Removing a Roadblock to Reforming Health Care: New York State Conference of Blue Cross \& Blue Shield Plans v. Travelers Insurance Company, 3 Conn. Ins. L.J. 127 (1997); Jana K. Strain \& Eleanor D. Kinney, The Road Paved with Good Intentions: Problems and Potential for Employer-Sponsored Health Insurance Under ERISA, 31 LOY. U. CHI. L.J. 29 (1999).

6. See, e.g., Farrell, supra note 5; Troy Paredes, Stop-Loss Insurance, State Regulation, and ERISA: Defining the Scope of Federal Preemption, 34 HARV. J. ON LEgIS. 233 (1997); William H. Pitsenberger, "An Apparently Irrational Distinction": A Suggestion for Using Equal Protection Arguments To Overcome Conflicts in ERISA Preemption, 32 J. HEALTH L. 307 (1999); Strain \& Kinney, supra note 5.

7. 536 U.S. 355 (2002).

8. 123 S. Ct. 1471 (2003).

9. 124 S. Ct. 2488 (2004).

10. That case was FMC Corp. v. Holliday, 498 U.S. 52 (1990). 
clauses in a way that would eliminate or minimize the distinction. Neither of these scenarios is likely in the near future, however. Although a federal "Patients' Bill of Rights" that includes amendments to ERISA might one day be enacted, none of the leading legislative proposals would eliminate special protections for self-insured health benefits plans. A change in the relevant judicial interpretations of ERISA is even less likely because the Congress that enacted ERISA clearly intended for the statute to protect self-insured benefit plans from state regulation.

With the statutory difference in treatment between insured and selfinsured plans unlikely to disappear any time soon, the reach of state regulation of health insurance rests on how many businesses choose to selfinsure their EHBPs. At present, the number is surprisingly high, owing in part to the popularity of a loophole in ERISA that enables employers without sufficient resources to bear the risk of their employees' health care costs to purchase "stop-loss" insurance-a product that reimburses the employer for costs above a specified threshold amount-and still qualify for ERISA's protection from state regulatory requirements.

ERISA also contains a second, less well-understood loophole, however, that states can exploit to minimize the number of EHBPs able to invoke ERISA as a shield against state regulation of health insurance: ERISA's text and structure permit states to regulate the terms and conditions of stoploss insurance. Some states have already taken advantage of this loophole to a limited extent, although none has exploited it as fully as they might. Correctly interpreted, ERISA provides state regulators with the tools to effectively staunch employers' ability to manipulate the statute's preemption provision for the sole purpose of avoiding state insurance mandates.

This Article explores the battle between employers who seek to maximize and state regulators who seek to minimize the scope of ERISA preemption. Part I describes the relevant statutory structure of ERISA and the implications of that structure, with emphasis on the three recent Supreme Court decisions that increased the legal importance of the distinction between insured and self-insured health plans. Part II describes how the availability of stop-loss insurance allows employers to exploit a loophole in ERISA's deemer clause in order to avoid exposure to state regulation. Part II also defends the role federal courts have played in permitting the exploitation of this loophole on the ground that it is consistent with ERISA's text and its underlying congressional intent. Part III describes how a loophole in ERISA's savings clause allows state regulators to close the deemer clause loophole. It argues that, as is true for the deemer clause loophole, the text and underlying intent of ERISA 
counsels that the courts should not intervene to block the exploitation of this loophole. When it enacted ERISA, Congress established a muddled set of rules. Properly understood, ERISA's ground rules should allow employers and regulators to battle to a stalemate.

\section{THE INSURANCE-SELF-INSURANCE GAP}

\section{A. ERISA's Structure}

In the early $1970 \mathrm{~s}$, as a response to a number of failures of employersponsored pension funds, Congress proposed to replace a patchwork of state pension plan regulations with a federal regulatory structure." In the process of drafting ERISA, however, Congress expanded the proposal's scope to preempt state laws that relate to any "employee benefits plan," including employer-provided health insurance." ${ }^{12}$ But while ERISA, as enacted, provides detailed substantive regulations of pension plans, it includes virtually no substantive regulation of EHBPs, ${ }^{13}$ leaving such plans largely unregulated, save for a few recently-enacted federal health benefits regulations, such as minimum hospital length-of-stay rules for childbirth, ${ }^{14}$ mental health care coverage requirements, ${ }^{15}$ and limits on preexisting condition exclusions. ${ }^{16}$

There is one significant exception, however, to ERISA's preemption of state laws that relate to health care plans. The statute's savings clause protects from preemption state laws that "regulate[] insurance."17 Although there is no legislative history explaining the addition of the

11. See, e.g., Patricia Butler, ERISA Preemption Manual for State Health Policy Makers, 2000 NAT'L ACAD. For STATE HeAlTh POL'y 5.

12. Although most ERISA benefits plans are employer-sponsored, other entities, such as labor unions, can also sponsor such plans. See 29 U.S.C. $\$ 1144$ (2000).

13. See Shaw v. Delta Air Lines, Inc., 463 U.S. 85, 91 (1983). ERISA and its regulations do provide for a number of procedural regulations of EHBPs. For example, administrators of EHBPs are fiduciaries and have a range of obligations as such, see 29 U.S.C. $\S 1002$ (2000); EHBPs must provide summary plan descriptions to participants, see 29 C.F.R. 2520.102-3 (2004); and ERISA provides plan participants with a federal cause of action to recover promised benefits that the plan fails to provide, 29 U.S.C. $\$ 1132$ (a) (2000).

14. Newborns' and Mothers' Health Protection Act of 1996, 42 U.S.C. $\$ 300 \mathrm{gg}-4$ (2000).

15. Mental Health Parity Act of 1996, 29 U.S.C. $\S 1185$ a (2000), 42 U.S.C. $\S 300 \mathrm{gg}-5$ (2000).

16. 26 U.S.C. $\$ 9801$ (2000); 29 U.S.C. $\$ 1181$ (2000); 42 U.S.C. $\$ 300 g g(2000)$.

17. 29 U.S.C. $\$ 1144$ (b) (2) (A) (2000). 
savings clause ${ }^{18}$ its presence clearly suggests that Congress did not intend for the preemption principle to go so far as to subvert traditional, core areas of state regulatory authority.

In ERISA's text, however, the savings clause is followed by the deemer clause, ${ }^{19}$ with the latter limiting the scope of the former. The deemer clause provides that employee benefit plans "shall [not] be deemed to be an insurance company or other insurer... or to be engaged in the business of insurance ... for purposes of any law of any State purporting to regulate insurance companies [or] insurance contracts . ..." ${ }^{20}$ Thus, ERISA preserves the traditional right of states to regulate the insurance industry, but those regulations may not extend to cover EHBPs, even though EHBPs often serve an insurance function and might otherwise find themselves subject to state laws governing insurance. ${ }^{21}$

The deemer clause's limitation on the scope of the savings clause makes sense only in the context of one of ERISA's underlying goals: providing a uniform legal structure for employers that operate in multiple states. ${ }^{22}$ Neither ERISA nor any other federal law requires employers to provide any fringe benefits. ERISA's supporters thought that by protecting large, multi-state employers from the burden of dealing with multiple sets of regulatory requirements, employers would be more likely to provide fringe benefits. ${ }^{23}$ The end result of Congress's attempt to balance the competing goals of deferring to traditional state functions and promoting legal uniformity is that states may regulate insurance companies, even if such regulations indirectly "relate to" EHBPs because such plans purchase insurance, but states may not directly regulate the plans themselves.

Supporters of increased regulation criticize as inequitable or outright illogical the fact that EHBPs enjoy greater freedom from state control than

18. Id.; Metropolitan Life Ins. Co. v. Massachusetts, 471 U.S. 724, 745 (1985).

19. 29 U.S.C. $\$ 1144$ (b) (2) (B) (2000).

20. Id.

21. Cf. House COMm. ON Educ. \& LABOR, ERISA OVERSight RePORT OF THE PENSION TASK FORCE OF THE SUBCOMM. ON LABOR STANDARDS 10 (Comm. Print 1977) (concluding that the deemer clause "create[s] what may amount to a legal fiction in a given circumstance" in which a plan engages in insurance activities).

22. See Ingersoll-Rand Co. v. McClendon, 498 U.S. 133, 142 (1990) (describing ERISA's purpose of ensuring that benefit plans are not subject to divergent regulatory schemes in different states); Pilot Life Ins. Co. v. Dedeaux, 481 U.S. 41, 46-47 (1987) (same).

23. Donald T. Bogan, ERISA: The Savings Clause, 502 Implied Preemption, and State Law Remedies, 42 Santa Clara L. Rev. 105, 118 n.51 (2001); Farrell, supra note 5; Patricia M. Ochmann, Managed Care Organization Manage To Escape Liability: Why Issues of Quantity $v$. Quality Lead to ERISA's Inequitable Preemption of Claims, 34 AKRON L. REV. 571, 580 (2001). 
do insurance companies when the two types of organizations serve the same purpose of guaranteeing the provision of needed medical care. ${ }^{24}$ This disparate treatment is not irrational, however, because state laws regulating insurance companies impose a less severe administrative burden on multistate employers than would state laws directly regulating EHBPs themselves. For a multi-state employer that wishes to self-insure its employees' health care benefits, inconsistent state regulatory requirements, if permissible, would impose upon it the cost of developing a separate insurance plan for its employees in each state. ${ }^{25}$ If that multistate employer purchases insurance for its employees, it might have to purchase different insurance policies for employees in each state, but the employer need not concern itself with the task of complying with different state regulations-such responsibility would fall on the insurance companies.

Admittedly, this distinction can appear minor, especially given that self-insured employers can (and often do) hire insurance companies to design and administrate their self-insured EHBPs. ${ }^{26}$ In other words, conflicting state regulations of EHBPs would not cause CEOs of large national companies to spend their late-night hours struggling to master the regulatory intricacies of all fifty states. But qualitative distinctions between relative burdens created by regulation must be made in any structure of federal preemption. Otherwise, all state regulation would be preempted, because all state laws can be said to have some attenuated effect on preempted subject matter. For example, without such qualitative distinctions, ERISA presumably would preempt state food handling laws because such regulations affect the available options and costs to employee

24. See, e.g., Margaret G. Farrell, ERISA Preemption and Regulation of Managed Health Care: The Case for Managed Federalism, 23 AM. J.L. \& MED. 251, 264 (1997); Douglas J. Witten, Regulation of "Doumstream" and Direct Risk Contracting by Health Care Providers: The Quest for Consumer Protection and a Level Playing Field, 23 AM. J.L. \& MED. 449, 466 (1997); cf. FMC Corp. v. Holliday, 498 U.S. 52, 65-66 (1990) (Stevens, J., dissenting) (stating that there is no rational reason to permit employee benefit plans to contract for certain rights vis-a-vis employees when state law prohibits similarly situated insurance companies from contracting for the same rights).

25. Of course, many multi-state employers chose to provide different health care plans to their employees in different states notwithstanding the administrative costs of doing so. See, e.g., David Reich-Hale, Big Employers Self-Funding HMO Costs, NAT'L UNDERWRrTER: LIFE \& HEAlth / Fin. SeRvices EdITION, Oct. 11, 1999, at S-21 (describing one large employer that self-insures its employee's medical care in one state but purchases third-party insurance in others).

26. Farrell, supra note 5. 
benefit plans that wish to provide lunch as a fringe benefit. ${ }^{27}$

Despite the fact that ERISA's differential treatment of EHBPs and third-party insurance companies that sell health insurance to EHBPs is logically defensible, this differential treatment leads to a troubling inequity for employees. If an EHBP purchases third-party insurance, it is classified as an "insured" plan, and state regulations govern any set of benefits that it purchases. If a plan self-insures, however, these same state regulations do not apply. Consequently, employees in an insured plan benefit from state regulatory protections, whereas similarly-situated employees in a selfinsured plan do not.

This apparent inequity is perhaps made more objectionable by the fact that few employees know whether their EHBP is insured or self-insured. "Self-insured" rarely means "self-administrated," as most self-insured plans hire a third-party administrator (TPA) for their EHBP (and, as noted above, TPA services are often provided by insurance companies).$^{28}$ This means that most employees in self-insured EHBPs submit claim forms to and have their covered medical expenses paid by an entity other than their employer, oblivious to the distinction that the TPA is paying claims with the employer's money rather than with its own. ${ }^{29}$

The extent of the consequence to employees of whether their benefits plan is insured or self-insured became clear in 1985 (if not before) when the United States Supreme Court decided Metropolitan Life Ins. Co. $v$. Massachusetts. ${ }^{30}$ Metropolitan Life concerned a Massachusetts law requiring group health insurance policies to provide a minimum level of benefits for mental health care. When two insurance companies sold policies to employee benefits plans without such a benefit, the Massachusetts Attorney General brought suit. The United States Supreme Court upheld a Supreme Judicial Court of Massachusetts judgment for the State ${ }^{31}$ on the ground that the Massachusetts mandate was an insurance regulation protected from preemption by the savings clause. In so doing, the Court rejected the insurance companies' argument that the savings clause should

27. See Russell Korobkin, The Failed Jurisprudence of Managed Care and How To Fix It, 51 UCLA L. REV. 457, 505 (2003).

28. BARRY F. FURROW ET AL., HEALTH LAW 423 (2d ed. 2000).

29. See, e.g., Ins. Bd. v. Muir, 819 F.2d 408, 409 (3d Cir. 1987) (noting that employees received Blue Cross and Blue Shield claim forms and received reimbursement from Blue Cross and Blue Shield but the Blues were providing administrative services for a self-insured plan).

30. 471 U.S. 724 (1985).

31. Id. at $734-35$. 
be read narrowly to protect only "traditional" insurance laws, such as those regulating insurance company reserves, and not "innovative" benefits mandates. ${ }^{32}$

The Metropolitan Life court noted that, as a result of its ruling, employees in insured plans and employees in self-insured plans would be treated differently under state laws, because the deemer clause would prohibit Massachusetts from applying the mandate to self-insured EHBPs. ${ }^{39}$ To the extent that it found this distinction problematic, however, the Court laid the blame on Congress's doorstep for structuring ERISA in the way that it did. ${ }^{34}$ This dicta was reaffirmed as holding five years later in FMC Corp. v. Holliday, ${ }^{35}$ the only deemer clause case the Supreme Court has ever decided. FMC Corp. concerned a self-insured EHBP with a subrogation clause, requiring the plan member to reimburse the plan for any medical care costs that the plan paid if the member recovered those costs in a liability action against a third party. ${ }^{36}$ A plan member who recovered such expenses from a third-party refused to reimburse the plan on the ground that a state law prohibited subrogation. ${ }^{37}$ The Court held that ERISA preempted the state law because it was an insurance regulation, and as such "[did] not reach self-funded employee benefits plans because the plans may not be deemed to be insurance companies, other insurers, or engaged in the business of insurance for purposes of such state laws."

State mandated benefits laws, like the law at issue in Metropolitan Life, ${ }^{39}$ were enacted as a reaction to the rise of managed care from the $1970 \mathrm{~s}$ to the 1990s. The speed with which managed care arrangements replaced traditional indemnity insurance as the dominant form of health insurance led to a nation-wide backlash against the perceived aggressiveness of insurer attempts to contain costs by limited benefits and services. ${ }^{40}$ State legislators introduced bills by the hundreds requiring insurers to cover a wide-range of benefits and otherwise mandating the terms of insurance contracts, and nearly every state passed a variety of specific mandates, if not

32. Id. at $739-47$.

33. Id. at 747 .

34. Id. at $747 \& \mathrm{n} .25$ (stating that the court "merely give[s] life to a distinction created by Congress in the 'deemer clause"" and citing legislative history).

35. 498 U.S. 52 (1990).

36. Id. at 54 .

37. Id. at 55 .

38. Id. at 61 .

39. Metropolitan Life, 471 U.S. at 728.

40. Ochmann, supra note 23. 
an entire "Patient's Bill of Rights." One researcher estimates that the number of state mandates rose from virtually none in 1970 to 850 in 1991 , with the largest rate of increase coming before $1988 .^{42}$

The explosion of mandated benefits laws protected from preemption by the savings clause means the stakes associated with an EHBP's choice between purchasing third-party insurance or self-insuring its members' medical care costs are high. By self-insuring, an employer can avoid paying the cost of dozens of state insurance mandates, from in vitro fertilization to chiropractic treatment, as well as related state insurance policy regulations, such as the law at issue in FMC Corp. prohibiting subrogation by insurance providers. While no one mandate is likely to significantly increase the cost of health insurance, the aggregate affect of mandates can be quite significant. $^{43}$ These savings, available only to self-insured plans, flow straight to the EHBP's - and thus the employer's-bottom line. ${ }^{44}$ Thus, the deemer clause not only affords different treatment to employers ex post based on the employer's decision to insure or self-insure, it also affects employers' ex ante incentives when making that choice. As a result, self-insurance is attractive not only to the small percentage of employers that operate in multiple jurisdictions ${ }^{45}$ and might wish to minimize the administrative costs of insuring employees subject to inconsistent state rules, but also to any

41. See Russell Korobkin, The Efficiency of Managed Care "Patient Protection" Laws: Incomplete Contracts, Rounded Rationality, and Market Failure, 85 CoRNELL L. REv. 1, 17-18 (1999).

42. Gail A. Jensen, State Mandates on Prizate Insurance, CATO REgulation: THE REview OF BuSINESS \& GOVERNMENT, Aug. 1, 1992, http://www.cato.org/pubs/regulation/ reg15n4g.html.

43. See, e.g., Renate M. Nellich, Executive Partnerships in Reinsurance, NAT'L UNDERWRITER: Life \& Health / Fin. Services Edition, Apr. 20, 1998, at 10 (reporting that benefits expenses among U.S. businesses grew from thirty percent to nearly forty-two percent of payroll between 1975 and 1998, with half the increase due to new mandated benefits).

44. In a perfectly functioning market in which employees had complete information and unlimited cognitive abilities, employers would have no incentive to provide less attractive fringe benefits to their employees than do competitors, because the employer would either have to spend the savings on other forms of employee compensation or risk losing its best employees. It is more plausible to assume, however, that while the availability of health care coverage affects many employees' choice of jobs, few employees consider the details of competing employers' health care plans when making such choices. See generally Korobkin, supra note 41 .

45. This percentage of employers has been reported to be as low as five percent. See Gail A. Jensen et al., State Insurance Regulation and Employers' Decisions to Self-Insure, 62 J. RISK \& INS. 185, 200 (1995) (describing the composition of their employer data set as including predominantly single-state employers). 
employers that wish to avoid costly regulatory protections that states require insurance companies to provide. $^{46}$

\section{B. The Supreme Court Expands the Reach of the Savings Clause}

As the above discussion explains, the broader the interpretation given to ERISA's savings clause, the larger the gap between the legal protections afforded employees enrolled in self-insured and insured health benefits plans, and consequently the greater the incentive of employers to selfinsure their medical benefits plans. In its last three terms, the Supreme Court decided two cases specifically involving the breadth of the savings clause in the context of health insurance and another that has indirect implications for the savings clause's importance. The Court resolved these disputes in ways that expand the savings clause's scope and importance. Thus, an indirect effect of the Court's rulings in Rush Prudential HMO $v$. Moran, ${ }^{47}$ Aetna Health Inc. v. Davila, ${ }^{48}$ and Kentucky Ass'n of Health Plans $v$. Miller $^{49}$ is to increase the incentive of employers to self-insure.

\section{Rush Prudential HMO v. Moran}

Rush Prudential HMO concerned one of the 1990s' most popular mandated benefits statutes, the status of which, under the savings clause, was disputed by the lower federal courts.

One of the most controversial features of managed health care is "utilization review," according to which a health insurer reviews treatments proposed by physicians to determine whether they are "medically necessary." If the insurer's representative determines that a procedure does not satisfy the insurer's standard of medical necessity, the insurer refuses to authorize payment for it. Although the patient may pay for the treatment out of pocket, the costs of medical procedures that are expensive enough to justify utilization review are prohibitive for most patients, so a utilization review denial usually means that the patient will not receive his desired treatment.

46. See, e.g., Peter Schmidt, Part I: The Basics of ERISA as It Relates to Health Plans, in EBRI ISSUE BRIEF NO. 167 (SPECIAL REPORT SR-31), at 5 (1995) (reporting that the growing ranks of self-insured plans are "influenced" by employer desire to escape expanding state regulations).

47. 536 U.S. 355 (2002).

48. 124 S. Ct. 2488 (2004).

49. 123 S. Ct. 1471 (2003).

50. See, e.g., Korobkin, supra note 27 , at 463 . 
One contributing factor to the public backlash against the health insurance industry in the 1990s was the perception that insurers were using utilization review as a method of minimizing costs by denying legitimate treatment requests. ${ }^{51}$ As a result, forty-one states enacted "external review" statutes, ${ }^{52}$ which require health insurers to permit patients to appeal adverse utilization review decisions to a neutral arbitrator and to pay for the treatment if that arbitrator determines that the treatment is medically necessary. Insurers challenged these regulations as preempted by ERISA, and a "circuit split" resulted. The Seventh Circuit held that the savings clause protected an Illinois external review statute. ${ }^{53}$ Meanwhile, the Fifth Circuit ruled that ERISA preempted a substantively identical Texas statute because the remedies provided under the statute conflicted with ERISA's remedy provisions. ${ }^{54}$ The Fifth Circuit's rule would deny the protection of state external review laws to any patient who receives his health insurance through an EHBP, thus treating members of insured and self-insured plans identically. The Seventh Circuit's rule would grant the same treatment to external review statutes as to the mental health benefits mandate at issue in Metropolitan Life, consequently providing rights to employees in insured plans but not those in self-insured plans.

Over a sharp dissent by four justices, ${ }^{55}$ the Supreme Court in 2002 upheld the Seventh Circuit's position that ERISA's savings clause protects state external review statutes and that such statutes are not otherwise preempted because they conflict with ERISA's remedy provisions. ${ }^{56}$ The decision was a major victory for supporters of managed care regulation. It also expanded the legal and practical significance of an employer's decision to self-insure its EHBP rather than purchase third-party insurance.

51. For an analysis of why it might make business sense for health insurers to engage in such a strategy notwithstanding built-in market constraints on strategic underperformance of contractual obligations, see Korobkin, supra note 41, at 2944 .

52. Mark C. Nielsen, Piercing the Preemptive Veil: Rush Prudential HMO v. Moran Opens the Door for Additional State Regulation of Managed Care Organizations, 14 HEALTH L. 15, 15 (2002) (noting that external review statutes have been enacted by forty-one states and the District of Columbia).

53. Moran v. Rush Prudential HMO, Inc., 230 F.3d 959 (7th Cir. 2000).

54. Corporate Health Ins., Inc. v. Texas Dep't of Ins., 215 F.3d 526 (5th Cir. 2000), modified and reinstated by 314 F.3d 784.

55. Rush Prudential, 536 U.S. at 388 (Thomas, J., dissenting). Chief Justice Rehnquist and Justices Scalia and Kennedy joined Justice Thomas's dissent.

56. Id. at 385,386 . 


\section{Aetna Health Inc. v. Davila}

The Supreme Court's decision in Rush Prudential HMO permits states to provide patients enrolled in insured (but not self-insured) EHBPs with procedural protections from erroneous utilization review denials, which has the indirect effect of providing EHBPs with a financial incentive to selfinsure. The Court's June 2004 decision in Aetna Health Inc. v. Davila ${ }^{57}$ further increased the incentive to self-insure by increasing the relative importance to patients of the external review statutes permitted under Rush Prudential HMO.

In theory, the legal system can adopt either (or both) of two approaches to prevent health insurance providers from minimizing costs by using the utilization review process to avoid providing services that satisfy the underlying medical necessity standard. One approach to this moral hazard problem relies on ex ante government regulation of services as a prophylactic device. In the case of utilization review, external review statutes serve this function. Providers are prevented by the external review process from refusing to provide at the time of sickness the level of care promised at the time of enrollment. The alternative approach relies on the threat of private litigation and resulting sanctions to deter careless or strategic behavior. Knowing that they can be sued by the patient for resulting damages should they improperly deny coverage of a requested treatment, providers will have an incentive to take appropriate care to furnish the services to which patients are entitled. They will also have an incentive in close cases to err on the side of providing questionable treatment to avoid the risk of litigation.

ERISA's remedy provisions permit a member of an EHBP to bring a lawsuit under ERISA to "recover benefits due to him under the terms of his plan," to "enforce his rights under the terms of the plan," or to "clarify his rights to future benefits under the terms of the plan." ${ }^{8}$ However, the Supreme Court has interpreted this portion of the statute narrowly, ruling that aggrieved plan participants can bring suit under the statute for the value of benefits improperly withheld but not for compensatory or punitive damages. ${ }^{59}$ The significance of this limitation for the utilization review process depends on whether a patient improperly denied medically necessary medical treatment may bring suit under specific state statutes or general state tort law that permits a broader range of remedies.

57. 124 S. Ct. 2488 (2004).

58. 29 U.S.C. $\S 1132$ (a) (1) (B) (2000).

59. Mass. Mutual Life Ins. Co. v. Russell, 473 U.S. 134, 144 (1985). 
Prior to 2000, most lower courts to address this question had held that ERISA's remedial provisions preempted all related state claims and, thus, an insurer's legal risk of a utilization review denial was limited to the cost of the desired treatment. ${ }^{60}$ Under this rule, the direct financial incentive to conduct the utilization review process carefully and generously is limited, which increases the attractiveness of ex ante prophylactic regulation embodied in external review statutes to critics of managed care.

The Supreme Court's Pegram v. Herdrich ${ }^{61}$ decision in 2000 cast doubt on the conventional wisdom that ERISA preempts state law claims against health insurers arising out of utilization review denials. At issue in the case was whether an HMO violates its fiduciary duties under ERISA by basing physician compensation in part on how successful physicians are at limiting resource usage for patient care. ${ }^{62}$ In answering this question in the negative, the Court explained that allowing a patient who is denied medically necessary care to maintain a cause of action for breach of fiduciary duty would essentially duplicate her existing right to challenge medical necessity determinations under state law. ${ }^{63}$ The Pennsylvania Supreme Court $^{64}$ and three federal circuit courts, $^{65}$ along with commentators, ${ }^{66}$ read the Pegram dicta as signaling that ERISA does not preempt state law causes of action arising from utilization review denials.

In last term's decision in Davila, the Supreme Court reviewed and reversed the Fifth Circuit's decision to this effect, validating the pre-Pegram conventional wisdom that, when a patient receives health care coverage through an EHBP, his ability to sue over a utilization review denial can be brought only under ERISA. ${ }^{67}$ The Court made no distinction in its opinion between the rights of employees in insured and self-insured EHBPs, despite the fact that it appears that one of the two plaintiffs in the case was

60. The leading case was Corcoran v. United Health Care, Inc., 965 F.2d 1321 (5th Cir. 1992). For a description of the state of the law prior to 2000, see Korobkin, supra note 27, at $494-97$.

61. 530 U.S. $211(2000)$.

62. Id. at 217.

63. Id. at 235.

64. Papps v. Asbel, 768 A.2d 1089 (Pa. 2001).

65. Cicio v. Does, 321 F.3d 83 (2d Cir. 2003); Land v. Cigna Healthcare of Fla., 339 F.3d 1286 (11th Gir. 2003); Roark v. Humana, Inc., 307 F.3d 298 (5th Cir. 2002). One circuit disagreed with this reading of Pegram, DiFelice v. Aetna U.S. Healthcare, 346 F.3d 442 (3d Cir. 2003), as did the dissenters in Rush Prudential, 536 U.S. at 388 (Thomas, J., dissenting).

66. See, e.g., Korobkin, supra note 27, at 520; Russell Korobkin, HMOs Get Authority To Strike a Fair Balance, L.A. TIMES, June 14, 2000, at B9.

67. 124 S. Ct. at 2493. 
enrolled in an insured EHBP while the other was a member of a selfinsured EHBP. ${ }^{68}$

In a concurring opinion, Justice Ginsburg (joined by Justice Breyer) argued that the Court should consider revisiting its earlier decision that read ERISA's remedial provisions so narrowly or, alternatively, that Congress should rewrite the statute. ${ }^{69}$ Unless and until this happens, however, it now seems clear that state statutes requiring external review provide the primary, if not the only, legal check on health insurance providers using utilization review to minimize the cost of providing health care, thus increasing the differential flexibility that self-insured EHBPs not subject to external review laws enjoy relative to insured EHBPs. In other words, Davila amplifies the difference in legal treatment of self-insured and insured EHBPs established in Rush Prudential-increasing the desirability of self-insurance to employers who want to maintain maximum flexibility to reduce the costs of providing health care coverage and decreasing the desirability of self-insurance to state regulators who wish to maximize the extent of legal protection for employees.

\section{Kentucky Ass' $n$ of Health Plans $v$. Miller}

In 2003, the Supreme Court followed its decision in Rush Prudential with another decision specifically concerning the breadth of the savings clause. As it did in Rush Prudential, the Court in Kentucky Ass'n again

68. The Court's opinion came in the consolidated cases of Aetna Health Inc. v. Davila and Cigna Healthcare of Tex., Inc. v. Calad. Davila, 124 S. Ct. at 2492-93. According to Cigna Healthcare's brief, Ruby Calad's EHBP was self-insured by her husband's employer, which in turn "delegated certain administrative responsibilities for the plan to petitioner Cigna Healthcare of Texas, Inc." Brief for Petitioner Cigna Healthcare of Texas, Inc. at 2, Davila (No. 02-1845). According to the joint brief of respondents Davila and Calad, Juan Davila "was a member of Aetna's HMO, which is not itself an 'ERISA plan." Brief for Respondents at 6, Davila (No. 02-1845). This language implies that Aetna, not Davila's employer, was the risk bearing entity. The Supreme Court's opinion does not state whether the employees were in insured or self-insured EHBPs-in fact, the difference between insured and selfinsured plans is mentioned nowhere in the opinion. The Court does state that the employees' "respective plan sponsors had entered into agreements with [Aetna and Cigna] to administer the plans." Davila, 124 S. Ct. at 2493 (emphasis added). This language could be read to imply that both insurance companies only administered the plans (and thus neither was the actual risk-bearing entity), but the better reading is probably that the Court did not think that whether risk was borne by the employees' employer or the insurance company administrator was relevant to the question of the preemptive effect of ERISA's remedial provisions.

69. Davila, 124 S. Ct. at 2503-04 (Ginsburg, J., concurring). 
favored state regulatory power over broad federal preemption under ERISA.

At issue in Kentucky Ass' $n$ were state "any willing provider" (AWP) laws, which require health insurers doing business in the state to contract with all physicians (or, in some cases other medical care providers such as chiropractors or pharmacists) willing to provide care to an insurer's customers in accordance with the insurer's standard terms and conditions. $^{70}$ At least half of the states have enacted some version of an AWP statute. ${ }^{71}$

Most managed care organizations (MCOs) oppose AWP laws on the ground that they take away a potent tool for containing health care costs. By selectively contracting only with certain providers, MCOs can force price concessions from those providers, both because they can guarantee a large quantity of business to the selected providers, and because the providers must worry that the MCO will refuse to contract with them at all if they do not grant such concessions. ${ }^{72}$ Patients' advocates, on the other hand, often support the laws on the grounds that they give patients greater treatment options and that they allow patients who move from one insurance plan to another the ability to maintain their pre-established doctor-patient relationships. ${ }^{73}$

As was the case with external review statutes, the circuit courts agreed that AWP laws "relate to" ERISA plans and are subject to federal preemption but split on the question of whether they are protected by the savings clause. ${ }^{74}$ The Fourth and Sixth Circuits determined that AWP statutes qualify as insurance regulations, and thus are saved; ${ }^{75}$ the Fifth and Eighth Circuits held that the laws fall outside the protection of the savings clause because they regulate entities outside the insurance industry or because they do not affect the allocation of risk between insurers and their customers. $^{76}$

70. Vickie Y. Brown \& Barbara R. Hartung, Managed Care at the Crossroads: Can Managed Care Organizations Survive Government Regulation?, 7 ANNALS HEALTH L. 25, 36 (1998); Butler, supra note 11, at 67; Justin Goodyear, What Is an Employee Benefit Plan?: ERISA Preemption of “Any Willing Provider" Laws After Pegram, 101 Colum. L. Rev. 1107, 1116 (2001).

71. Farrell, supra note 5, at 270.

72. See, e.g., Korobkin, supra note 27 , at 510.

73. Id. at 509-10.

74. Id. at 511-12.

75. Kentucky Ass'n of Health Plans v. Nichols, 227 F.3d 352 (6th Cir. 2000); Stuart Circle Hosp. Corp. v. Aetna Health Mgmt., 995 F.2d 500 (4th Cir. 1993); see also Korobkin, supra note 24, at 512 .

76. Prudential Ins. Co. of Am. v. Nat'l Park Med. Ctr., 154 F.3d 812 (8th Cir. 1998); 
The Supreme Court, this time in a unanimous decision, followed the circuit courts that gave a broader reading to the savings clause and held that ERISA does not preempt the Kentucky statutes. In so doing, the Court renounced the complicated, multi-part test for determining whether a state law "regulates insurance" that it introduced in Metropolitan Life and replaced it with a simpler, easier-to-satisfy test. Under the rule enunciated in Kentucky Ass'n, in order to qualify as a law that regulates insurance and therefore receives protection from the savings clause, the state law in question need only be "specifically directed" at the insurance industry (as opposed to being a law of general applicability) and "substantially affect" an insurer's insurance practices (as opposed to being a law that affects insurance companies only in their non-insurance-related capacities) ${ }^{77}$

\section{The Implications of the Court's Savings Clause Jurisprudence}

Since ERISA was enacted more than a quarter-century ago, the Supreme Court's jurisprudence has tilted, on balance, in favor of preemption. ${ }^{78}$ Going back as far as 1983, the Court has read the preemption clause broadly, finding that ERISA preempts a wide range of state laws because they either have a "reference to" or have a "connection with" EHBPs. ${ }^{79}$ In its 1995 decision in New York State Conference of Blue Cross and Blue Shield Plans $v$. Travelers Insurance Co., ${ }^{80}$ the Court narrowed the scope of ERISA preemption somewhat, but also suggested that the scope of preemption would continue to be broad. The Court's decisions in Rush Prudential HMO and Kentucky Ass'n reinforce this reading of Travelers, because the Court declined to address the underlying assumption of its holdings that the state laws at issue did in fact "relate to" ERISA plans, and thus were the subject of preemption.

Texas Pharmacy Ass'n v. Prudential Ins. Co. of Am., 105 F.3d 1035 (5th Cir. 1997); see also Korobkin, supra note 24, at 512.

77. Kentucky Ass'n of Health Plans v. Miller, 123 S. Ct. 1471, 1479 (2003).

78. The Court has drawn its share of criticism for this. See, e.g., Farrell, supra note 5; Catherine L. Fisk, The Last Article About the Language of ERISA Preemption? A Case Study of the Failure of Textualism, 33 HARV. J. ON LEGIS. 35 (1996); Korobkin, supra note 27; Saya, supra note 5, at 160; Susan J. Stabile, Preemption of State Law by Federal Law: A Task for Congress or the Courts?, 40 VILL. L. Rev. 1, $31-35$ (1995); Deborah J. Massaro, Comment, Removal of the ERISA Preemption Shield: Will the Third Circuit's Approach Make a Difference? - In re U.S. Healthcare, Inc., 26 DEL. J. CORP. L. 585, 592-93 (2001); Nicole Weisenborn, Note, ERISA Preemption and Its Effect on State Health Reform, 5 KAN.J.L. \& PUB. POL'Y 147 (1995).

79. Shaw v. Delta Air Lines, Inc., 463 U.S. 85, 96-97 (1983).

80. 514 U.S. 645 (1995). 
But while the Court continues to read the preemption clause broadly, it also continues to read the savings clause broadly. As a general statement, it is fair to say that the Court has promoted federal authority through the preemption clause, while simultaneously protecting state authority through the savings clause. An unintended consequence of this doctrinal approach is that it maximizes the gap in treatment that employees in selfinsured and insured plans receive under ERISA.

\section{EXPLOITING THE DEEMER GLAUSE LOOPHOLE}

Part I described how a broad interpretation of ERISA's savings clause juxtaposed with ERISA's deemer clause creates a significant incentive for EHBPs to self-insure their members' health care costs rather than purchase third-party health insurance. No matter how great this incentive, however, EHBPs will not choose to self-insure if they cannot afford to assume the risk of catastrophic medical care claims in a given year. Stop-loss insurance protects EHBPs from catastrophic losses, thus making self-insurance feasible for even small employers and thereby facilitating widespread avoidance of state insurance regulations.

By using stop-loss insurance to minimize insurance risk while simultaneously avoiding state regulation, EHBPs exploit a loophole in ERISA's statutory structure. To the chagrin of supporters of greater regulation of health insurance, however, this loophole is consistent with the plain language of ERISA, and it is not inconsistent with ERISA's structure. Courts thus have properly refused to heed the calls of regulation supporters to close the loophole, although their analyses often make the issue much more complicated that it should be.

\section{A. The Economics of Self-Insurance}

A managed care organization or a traditional indemnity insurance company that sells third-party health insurance provides two distinct services. First, it administers the insurance plan, which includes establishing contracts with medical care providers and reviewing and paying covered claims. Second, it assumes the risk that in any given year its customers will incur medical care costs that are higher than their actuarial, average expected cost. This latter service is often described as bearing "insurance risk." Insurance companies, of course, do not provide such services for free. The premiums they charge can be understood as consisting of the customer's expected medical care cost, plus an extra

81. Butler, supra note 11 , at 62 . 
amount to cover the costs of administration and insurance risk, including the company's profit margin. ${ }^{82}$

By self-insuring rather than purchasing insurance, employers, in theory, can avoid the costs of paying a third-party insurer to provide administrative services. In reality, many employers contract with third parties to serve as TPAs and administer their health care benefits; ${ }^{83}$ this is true even of extremely large companies with tens of thousands of employees. ${ }^{84}$ Presumably, this is because TPAs' expertise in administration makes it cheaper for self-insured EHBPs to contract for administrative services rather than to provide them "in-house." This suggests that EHBPs are unlikely to save substantially, if at all, on administrative costs by selfinsuring. ${ }^{85}$

Whether it is in an EHBP's interest to self-insure, then, depends on the extent of the insurance risk that it would undertake. An EHBP with few beneficiaries can expect a large variance in annual medical care costs. ${ }^{86}$ The costs incurred by a single member who suffers a catastrophic illness could be far greater than a plan's actuarially expected medical costs, resulting in severe cash-flow problems or even insolvency. The risks associated with extreme annual fluctuations decline as the size of the EHBP increases; that is, the more members in an EHBP, the lower the expected annual variance of the plan's expenses. ${ }^{87}$ Insurance companies have an advantage relative to individual employers in managing insurance risk because they pool the individual risks of a large number of customers. ${ }^{88}$ Extremely large employers, however, have a pool of individual

82. Laurence Baker, Managed Care and Social Welfare: What Has Managed Care Really Done to the U.S. Health Care System?, in The Political Economy of Health Care Reforms 35-39 (Huizhong Zhou ed., 2001).

83. Butler, supra note 11 , at 90.

84. Id.

85. Cf. Jensen et al., supra note 45 , at 187 (finding that "research suggests that... administrative costs for self-insured plans are actually higher than those of purchased plans containing the same coverage").

86. Risk in insurance pools is $1 / \mathrm{N}$ times the variance of each individual ( $\mathrm{N}$ is the number of members in the pool). The larger the pool and the more diverse the population, the lower the variance in risk. CHARLES E. Phelps, HeAlTh ECONOMICS 331 (2003).

87. 1 Eric Mills Holmes \& Mark S. Rhodes, Holmes' Appleman on InSurance, 2D $\$ 1.2$ (1996) [hereinafter APPLEMAN]; ROBERT E. KEETON \& ALAN I. Widiss, InSURANCE LAW: A Guide to Fundamental Principles, Legal Doctrines, and Commercial Practices 13 (Student ed. 1988).

88. APPLEMAN, supra note $87, \S 2.18$ (commenting that generally, only large corporations fully self-insure). 
risks sufficiently large to minimize its insurance risk, reducing the value of purchasing third-party insurance. ${ }^{89}$ The consequence is that the EHBPs of only very large employers should routinely self-insure, while most other EHBPs should be willing to pay an insurance company a premium for the service of bearing their insurance risk. ${ }^{90}$

By allowing self-insured EHBPs to avoid state regulation, however, ERISA provides EHBPs three additional incentives to self-insure. First, a self-insured EHBP with members in multiple states can provide a single set of benefits for all of its employees and avoid the cost of conforming to conflicting regulations and mandates in different jurisdictions. Second, that set of benefits can be more limited, and thus cheaper to provide, than the set of benefits the EHBP would have to provide should it purchase third-party insurance encumbered by state mandates. Third, by selfinsuring, EHBPs can avoid premium taxes on health insurance purchases imposed by most states (usually for the purpose of subsidizing state insurance pools to cover the uninsured or difficult-to-insure), ${ }^{91}$ as well as other state regulatory requirements that can be costly, inconvenient, or both, such as regulations concerning what information insurers must be provided to consumers. ${ }^{92}$ While minimizing administrative burdens of multi-state employers is a goal of ERISA, there is no indication that ERISA's drafters affirmatively desired to protect EHBPs from all costs associated with state insurance regulation. If that were Congress's goal, the statute presumably would not have included the savings clause.

Measuring the absolute popularity of self-insurance among employers at any given time is a notoriously inexact science, because understandings

89. See, e.g., Butler, supra note 11, at 62 .

90. An exception to this rule might be some employers with very young workforces in states that require certain types of insurers (often HMOs) to sell coverage at "community rates"-that is rates that do not discriminate based on the demographics or claims experience of particular employer groups. Cf. David Reich-Hale, Big Employers Self-Funding HMO Costs, NAT'L UNDERWRITER: LifE \& HEALTH / FIn. SERVICES EdITION, Oct. 11, 1999, at S21 (reporting that in 1998 sixty-three percent of employees in HMOs were in communitybased plans). These employers might find self-insurance a particularly desirable arrangement because they can avoid paying insurance company rates that substantially exceed their expected claims experience. See, e.g., Michael Prince, Self-Funded Health Plans Not Expanding Ranks, Bus. INS., Feb. 21, 2000, at 3 ("Employers in community-rated HMOs can generally save money by going into a self-funded HMO if their claims experience is better than that of the overall group insured by the HMO.").

91. See, e.g., Prince, supra note 90 , at 3.

92. See, e.g., Karl Polzer \& Patricia A. Butler, Employee Health Plan Protections Under ERISA, 16 HeALTH AFF. 93, 94-95 (1997). 
of what constitutes self-insurance vary among employers and because employers often offer employees a choice of plans, ${ }^{93}$ some of which might be insured and others self-insured. Assessing the impact of ERISA's favorable regulatory treatment of self-insured EHBPs on employers' decisions about whether to self-insure is even more problematic because many exogenous factors can affect the relative benefits of self-insuring versus insuring. ${ }^{94}$ Notwithstanding these notes of qualification, however, there is no doubt that self-insurance has become more popular among employers, by many fold, over the last three decades, and that the desire to avoid state benefits mandates and premium taxes can explain at least some of this increase in popularity.

Employers shifted from insured to self-insured EHBPs in large numbers in the 1980s. According to one study, only four percent of employee health benefits were paid for by self-insured plans at the time of ERISA's enactment, while forty-seven percent of EHBPs self-insured at least their primary health benefits plan in $1986 .{ }^{95}$ According to other studies, that number rose to sixty-seven percent in $1992,{ }^{96}$ and forty-six percent of all employees who received health coverage as an employment benefit were enrolled in self-insured EHBPs by that year. ${ }^{97}$

93. A recent Kaiser Family Foundation study reported that nearly half of all employees covered by employment-based health plans had a choice of three or more different plans, while only thirty-eight percent were offered only one plan. THE KAISER FAMILY FOUND. \& Health Research \& Educ. Trust, Employer Health BeneftTs: 2003 AnNual SuRvey 64 (2003) [hereinafter KFF/HRET].

94. For example, high interest rates give employers an incentive to self-insure, because self-insuring allows them to keep cash until an employee needs care rather than paying a premium to the insurer at the beginning of the year. See, e.g., Daniel M. Fox \& Daniel C. Shaffer, Health Policy and ERISA: Interest Groups and Semipreemption, 14 J. HEALTH POL. POL'Y \& L. 239, 252 (1989). Self-insurance also enables employers to collect detailed claims data in order to try to manage employee benefit costs that insurance companies often will not provide because they fear that employers with favorable claims experience might shop for cheaper insurance or decide to self-insure. Michael Prince, Health Plans Shifting Approach as Costs Climb, Bus. InS., Feb. 25, 2002, at 16. at 1 .

95. Steve Kalmeyer, ERISA and State Health Reform, HEALTH POL'y MONITOR, Spring 1997,

96. A. Foster Higgins \& Co., Foster Higgins Health Care Benefits Survey 19 (1992), cited in Jeffrey Lenhart, ERISA Preemption: The Effect of Stop-Loss Insurance on Self-Insured Health Plans, 14 VA. TAX Rev. 615, 615 n.1 (1995).

97. Bureau of Labor Statistics, U.S. Dep'T OF Labor, Employee Benefits in MEdiUm and LaRge Private Establishments (1993); see also Gregory Acs et al., Self-Insured Employer Health Plans: Prevalence, Profile, Provisions, and Premiums, 15 Health AFF. 266-78 (1996) (estimating that forty percent of private sector employees and their dependents were 
The strong correlation between the rise of managed care financing arrangements and the corresponding explosion of state insurance regulation on the one hand and the steep rise in employer self-insurance on the other does not, of course, itself prove that the former caused the latter. Many self-insured employers offer a rich set of benefits, suggesting that many factors affect an employer's decision to self-insure, not just the desire to save money by offering fewer benefits. Still, it seems clear that at least some and probably much of the increase in self-insurance can be attributed to the desire to use ERISA to avoid state regulations of one type or another ${ }^{98}$ As an illustration, one study attempting to explain the causes of employer shifts to self-insurance in the 1980 s found that the desire to avoid the costs of state insurance mandates and premium taxes explained about two-thirds of the increase in employer self-insurance observed in the early part of that decade. ${ }^{99}$

Although self-insurance rates have fluctuated in the last decade, ${ }^{100}$ at least half of workers with employment-based health care benefits are probably in self-insured plans today. One recent study conducted by the Kaiser Family Foundation (KFF) reports that, in 2003, fifty-two percent of workers with employment-based health care benefits were in self-insured plans, down slightly from the fifty-six percent figure reported by a KPMG study in $1996 .{ }^{101}$ By further increasing the differential susceptibility to state regulation of insured and self-insured EHBPs, the Supreme Court's expansion of ERISA's savings clause over the last three years suggests that this percentage is likely to increase in coming years.

enrolled in self-insured plans).

98. Cf. Donald T. Bogan, Protecting Patient Rights Despite ERISA: Will the Supreme Court Allow States to Regulate Managed Care?, 74 TUL. L. REv. 951, 1005 (2000) (claiming a causal relationship between state regulation and the increasing number of self-insured EHBPs).

99. Jensen et al., supra note 45 , at 208 . In the authors' sample, state regulation could not explain further increases in self-insurance later in the decade, which does suggest other factors are also at play. The authors hypothesize that the different results for the different time periods analyzed might be the result of greater state regulatory activity early in the decade or employers most concerned with avoiding the costs of state regulation having already converted to self-insurance early in the decade. Id. at 210-11.

100. Relatively small fluctuations in the rate of self-insurance can be due to factors unrelated to the different regulatory treatment of insured and self-insured EHBPs, such as the extent of price competition in the insurance market and changes in the popularity of different types of managed care, some of which are easier to finance through self-insurance than others. For a good discussion, see Jon R. Gabel et al., Self Insurance in Times of Growing and Retreating Managed Care, 22 HEALTH AFF. 202 (2003).

101. KFF/HRET, supra note 93 , at 125 exhibit 10.1 . 


\section{B. Stop-Loss Insurance}

The regulatory benefits of self-insurance created by ERISA help to explain why many EHBPs would like to self-insure, but the insurance risk traditionally associated with self-insurance should remain a major disincentive for all but the largest employers. What is most astonishing about the extent to which employers self-insure is that, although very large employers remain the most likely to self-insure their EHBPs, even small to mid-sized employers self-insure in significant numbers. According to the General Accounting Office, in 1992, thirty-two percent of employees working for companies with more than 100 employees were covered by a self-insured plan. ${ }^{102}$ KFF reports that in 2003 only ten percent of covered employees in firms with fewer than 200 workers were in self-insured plans, down from the twenty-four percent reported by KPMG in 1996, but KFF also reports that fully fifty percent of covered employees in mid-sized firms (200-999 employees) currently receive their benefits from self-insured plans. ${ }^{103}$

The surprising popularity of self-insurance among small and mid-sized employers can be attributed significantly, although not entirely, to a product known as "stop-loss" insurance (or, when issued to an EHBP, sometimes known as "medical stop-loss" insurance). ${ }^{104}$ Although the details can often be complicated, the basic concept of stop-loss insurance is simple. The EHBP pays for its employees' covered medical care expenses from a trust fund established for that purpose or from current revenues. ${ }^{105}$ At the same time, the EHBP purchases third-party stop-loss insurance for itself-not for its members-that covers losses suffered by the plan as the result of members' catastrophic claims against it. ${ }^{106}$ The stop-loss insurance

102. U.S. Gen. ACCounting Office, GAO/HEHS-95-167, Employer-Based Health Plans: Issues, TRENDS, AND CHALlenges POSED By ERISA 49 (1995) [hereinafter GAO, Issues AND TRENDS].

103. KFF/HRET, supra note 93, at 125 exhibit 10.1 .

104. A large majority of self-insured EHBPs purchase stop-loss coverage, and nearly all small and medium-sized employers that self-insure purchase stop-loss coverage to cap their exposure. A. FOSTER HIGGINS \& CO., supra note 96, at 19 (reporting sixty-four percent of selfinsured employers with more than one thousand employees purchased stop-loss coverage, and ninety-six percent of self-insured employers with fewer than one thousand employees purchased stop-loss coverage).

105. Paredes, supra note 6, at 249.

106. Id.; see also Deborah Shalowitz Cowans, Employers Have Various Options in Covering Catastrophic Care, Bus. Ins., Aug. 2, 1999, at 3 ("For the most part,... self-insured employers... rely on stop-loss insurance to fund and manage catastrophic health care 
pays the EHBP when the plan's losses in a given year exceed a predetermined amount, known as the "attachment point."

Stop-loss policies can have either "specific" attachment points, "aggregate" attachment points, or both. If the policy has a specific attachment point, usually a dollar amount, the stop-loss insurance reimburses the EHBP for any individual employee's medical costs in excess of the attachment point. If the policy has an aggregate attachment point, usually expressed as a percentage of the EHBP's actuarially determined expected annual cost, the insurance is tapped if the EHBP pays out more than that amount for total covered member medical care costs. ${ }^{107}$

Stop-loss coverage as a risk management tool for EHBPs is not a new innovation. Just as traditional insurance providers usually "reinsure" part of their insurance risk in order to minimize exposure to catastrophes, even large EHBPs with an actuarially sound risk pool purchase stop-loss insurance just in case an unexpected scourge has a disproportionately catastrophic effect on its members. ${ }^{108}$ An innovation that made possible the vast expansion of self-insured EHBPs in the 1980s and 1990s, especially among smaller employers, ${ }^{109}$ was the sale of stop-loss policies with such low attachment points-some as low as $\$ 500^{110}$ - that the EHBP maintained little insurance risk or none at all. ${ }^{111}$ For example, in terms of the insurance

claims.").

107. Paredes, supra note 6, at 249.

108. One mid-1990s study found that sixty-one percent of all large employers self-fund with stop-loss insurance, while only thirteen percent self-fund without stop-loss insurance. Ken McDonnell, Questions and Answers on Health Insurance Benefit Issues, in EBRI IssuE BRIEF No. 164, at 12 (1995).

109. Cf. Jerry Geisel, ERISA Showdown Likely over State Stop-Loss Bill, BuS. INS., May 3, 1999, at 1 (reporting that small employers favor stop-loss policies with low attachment points, whereas employers with more than 500 employees usually purchase policies with higher attachment points).

110. See Key Patients' Protections: Lessons from the Field: Hearing Before the Senate Comm. on Health, Education, Labor and Pensions of the United States, 106th Cong. 11 n.9 (1999) (statement of Kathleen Sebelius, Kansas Insurance Commissioner) (observing that small employers will often "self-fund only a very small dollar amount ( $\$ 500)$ [of their employees' health benefits] and then buy stop-loss insurance for the rest of their liability").

111. See, e.g., Md. Bars 'Stop-Loss' Policies, Ins. Accounting, Nov. 1, 1999, at 1 (quoting Maryland Insurance Commissioner describing the terms of one insurer's stop-loss policy). Anecdotal evidence indicates that stop-loss policies with extremely low attachment points became prevalent in the mid-1990s. See Polzer \& Butler, supra note 92, at 98 (noting that many state insurance regulators reported an "increasing number of small businesses are ostensibly self-insuring while also purchasing stop-loss policies covering individual claims exceeding $\$ 500$ or $\$ 1,000 ")$. 
risk it maintains, there is no difference between an EHBP that purchases third-party insurance policies for each employee with a $\$ 500$ annual deductible and an EHBP that offers a self-insured benefit plan with a $\$ 500$ deductible and maintains stop-loss insurance with a $\$ 500$ specific attachment point per employee-in both examples, the employer retains no insurance risk at all. By hiring a TPA and purchasing stop-loss coverage with low attachment points (sometimes from the same company), selfinsured EHBPs can virtually eliminate all of the costs of self-insurance while taking advantage of the beneficial regulatory treatment provided to them by virtue of ERISA.

In light of the Supreme Court's recent expansive interpretations of ERISA's savings clause, the incentives for EHBPs to self-insure and purchase stop-loss insurance rather than purchase third-party health insurance are now more compelling than ever, although unrelated market forces that have caused sharp increases in stop-loss insurance premiums in the last few years could temporarily dampen this incentive. ${ }^{12}$

\section{Legal Challenges}

The late 1980s and early 1990s brought a number of legal challenges to the use of self-insurance arrangements coupled with stop-loss insurance by EHBPs attempting to avoid state insurance regulations. All of these challenges failed, as they should have, although the courts' reasoning was not always as precise as it might have been.

In the typical challenge, a self-insured EHBP that carries stop-loss insurance attempts to enforce a provision of the plan that is contrary to state law, or a plaintiff attempts to enforce a provision of state law that is contrary to the terms of a plan against an EHBP that carries stop-loss insurance. For example, in United Food $\mathcal{E}^{2}$ Commercial Workers v. Pacyga, ${ }^{113}$ a state anti-subrogation law prevented insurance companies from recovering benefit payments made to insured members who collected duplicate

112. See, e.g., Karen Cutts, Using RRGs To Fund Stop-Loss Exposures in Self-Funded Medical Plans, Nat'l Underwriter: Prop. \& Casualty / Risk \& Benefits Mgmt. Edition, Apr. 7, 2003, at 33 (reporting current increases in medical stop-loss insurance premiums of twenty to fifty percent); Michael Prince, Employers To Feel Bite of Health Reinsurance Rate Hikes, Bus. INS., Oct. 23, 2000, at 30 (describing a number of trends, in addition to health care inflation, driving up stop-loss insurance rates); Michael Prince, Reinsurers Shifting More Health Risks to Buyers, BUS. INS., Oct. 28. 2002, at 10 (reporting that the price of medical stop-loss policies increased twenty to thirty percent in 2002 as a consequence of insurers suffering losses in other product lines and the reduction of overall capacity in the market).

113. 801 F.2d 1157 (9th Cir. 1986). 
benefits from another party, such as a tortfeasor. ${ }^{114}$ When an EHBP sought subrogation according to the plan's coverage terms, the member, relying on the Supreme Court's distinction between self-insured and insured plans drawn in Metropolitan Life and FMC Corp., argued that the plan's subrogation clause was unenforceable because the plan's stop-loss coverage rendered it "insured" and thus not shielded from state regulation by the deemer clause.

The Ninth Circuit in United Food, like the Fourth ${ }^{115}$ and Sixth ${ }^{116}$ Circuits in similar cases, ruled that the deemer clause did in fact protect the EHBP from the state regulation in question, notwithstanding the fact that the EHBP purchased stop-loss insurance. ${ }^{117}$ The usual justification is that the purchase of stop-loss insurance fails to render an EHBP "insured" for ERISA purposes because the EHBP maintains direct liability to plan members, while the stop-loss insurer is liable only to the plan, not to individual members. ${ }^{118}$ Therefore, as some courts have explained, an EHBP with stop-loss insurance would be liable to plan members for the cost of their health care even if the stop-loss insurer were to become insolvent, and conversely, members would have no claim against a stop-loss insurer if the employer went bankrupt, while an EHBP that purchases third-party health insurance for its members would have no liability to those members

114. Id. at 1159.

115. Talquin v. Thompson, 928 F.2d 649 (4th Cir. 1991).

116. Lincoln Mut. Cas. Co. v. Lectron Prods., Inc., 970 F.2d 206 (6th Cir. 1992). Lincoln Mutual explicitly overruled an earlier, contrary decision in Northern Group Services, Inc. $v$. Auto Owners Ins. Co., 833 F.2d 85 (6th Cir. 1987). Lincoln Mutual, 970 F.2d at 210 n.3. An earlier Sixth Circuit decision in Michigan United Food $\mathcal{E}^{\circ}$ Commercial Workers Unions $v$. Baerwaldt, 767 F.2d 308 (6th Cir. 1984), held that an EHBP that purchased stop-loss coverage must abide by a state insurance regulation, $i d$. at 313 , and is thus sometimes cited as conflicting authority, see, e.g., Paredes, supra note 6, at 256-57. The Baerwaldt decision, however, was based on the court's understanding from the plaintiff's complaint that the insurance company "will pay all benefits in excess of claims liability limit under the group policies"-that is, that the stop-loss insurance insured the plan members health care costs directly rather than insuring the plan itself. $767 \mathrm{~F} .2 \mathrm{~d}$ at 313 . Thus, while the court might have misunderstood the nature of the EHBP's arrangement with the insurance company, based on its understanding that benefits were provided to plan members by an insurance company rather than by the EHBP itself, its holding is not inconsistent with Lincoln Mutual, United Food, or Talquin.

117. 801 F.2d at 1161-62.

118. See Talquin, 928 F.2d at 653 (noting that Talquin's plan is directly liable to Talquin's employees and the stop-loss insurance covers the plan); United Food, 801 F.2d at 1161-62 (noting that "no insurance is provided to the participants"). 
if the insurance company became insolvent. ${ }^{119}$

Whether or not this distinction is functionally significant, however, it is irrelevant under ERISA. The relevant distinction between insured and selfinsured EHBPs for ERISA's purposes is that members of an insured plan have a contract with an insurance company, whereas members of a selfinsured plan have a contract only with the plan. ERISA distinguishes between insurance companies, which states may regulate, and EHBPs themselves, which states may not regulate, but the statutory text never makes a distinction between insured and self-insured plans per se. The plain language of ERISA requires courts to ask only whether the terms of a plan member's health insurance contract are provided by an EHBP or by a third-party insurance company - the deemer clause, recall, states only that an employee benefit plan may not be regulated like an insurance company. ${ }^{120}$ If an insurance company covers the member, state law may override terms of the insurance contract and substitute different or additional terms. If the EHBP itself covers the member, state law governing insurance companies may not override the terms of the insurance contract because states may not regulate EHBPs as insurance companies. So, for example, if an insurance company issues a policy to an EHBP member that excludes coverage for mental health care, a state mental health care mandate can nullify that exclusion and effectively rewrite the contract between the individual and the insurance company. On the other hand, if an EHBP enters into an equivalent contract with a plan member, the deemer clause prohibits the same state mandate from overriding the exclusion, even though the EHBP behaves functionally like an insurance company vis-à-vis its members.

In Metropolitan Life, the Supreme Court observed that a consequence of ERISA, in the context of the issues raised in that case, is that insured and self-insured plans receive different treatment. This observation is correct. Unfortunately, lower courts have sometimes misinterpreted this observation as being equivalent to a statement that the distinction between insured and self-insured plans is itself doctrinally relevant, which it is notthese terms of art never appear in ERISA's text. This error has led to a serious analytical tangle, as courts struggle to determine whether EHBPs that directly insure their members' health care costs and purchase stop-loss insurance for themselves are functionally "insured" or "self-insured." Such

119. See Am. Med. Sec., Inc. v. Bartlett, 111 F.3d 358, 364 (4th Cir. 1997); Georgetown Univ. Hosp. v. Reliance Standard Life Ins. Co., No. 97-1912, 1999 U.S. App. Lexis 7803, at *5-*6 (4th Cir. 1999).

120. 29 U.S.C. $\S 1144$ (b) (2) (B) (2000). 
EHBPs appear to be self-insured, in the sense that they bear the insurance risk of their members' illnesses and injuries rather than paying a thirdparty to bear that risk. On the other hand, they appear to be insured from a functional perspective, in the sense that they purchase insurance coverage to protect themselves from losses.

Some courts have responded to the confusion over the terms "insured" and "self-insured" by attempting to determine whether an EHBP is predominantly insured or self-insured. For example, in Brown $v$. Granatelli, ${ }^{121}$ the Fifth Circuit found that an EHBP with high-attachment point stop-loss coverage was self-insured and protected from state law by ERISA's deemer clause. ${ }^{122}$ It suggested in dicta, however, that an EHBP with low-attachment point stop-loss insurance likely would be considered an "insured" plan subject to state regulation. ${ }^{123}$ Other courts have followed the Fifth Circuit in suggesting that whether an EHBP is subject to state regulation might depend on the specific level of its stop-loss insurance's attachment point. ${ }^{124}$

This type of analysis is fundamentally misguided, because whether an EHBP maintains the actual insurance risk associated with employee illness bears no direct relevance to the question of whether the deemer clause, according to its text, prohibits state regulation of its members' health insurance contracts. Courts need only ask which entity promises to pay the health care costs incurred by plan members. If the EHBP must pay these costs, and thus acts as an insurer of its employee's health care, the state may not regulate the provisions of the employee-EHBP contract, and the plan is therefore "self-insured" according to the Metropolitan Life dichotomy. If a third-party insurance company bears the insurance risk of the employee's health care, the state may regulate the insurance contract, and the plan is therefore "insured" under Metropolitan Life. Whether a selfinsured plan does or does not purchase stop-loss insurance, or whether that stop-loss insurance has a low or high attachment point, is simply irrelevant, at least under a close reading of ERISA's text.

121. 897 F.2d 1351 (5th Cir. 1990).

122. Id. at 1355 .

123. Id.

124. See Bricklayers Local No. 1 Welfare Fund v. La. Health Ins. Ass'n, 771 F. Supp 771, 774 (E.D. La. 1991); Thompson v. Talquin Bldg. Prods. Co., C.A. No. 89-0082-H, 1990 U.S. Dist. LEXIS 11380 (W.D. Va. 1990); Associated Indus. of Missouri v. Angoff, 937 S.W.2d 277, 283 (Mo. Ct. App. 1996). 


\section{Should Courts Close the Loophole?}

Many observers have criticized the differential treatment that selfinsured and insured EHBPs receive vis-à-vis state law. ${ }^{125}$ Following the Supreme Court's lead in Metropolitan Life, ${ }^{126}$ however, most attribute responsibility for the distinction to Congress, which drafted ERISA, rather than to the courts, whose job is only to interpret the statute. ${ }^{127}$ Wise or not as a matter of policy, it would be impossible for courts to eliminate this distinction entirely without reading the deemer clause out of the statutea result that would be inconsistent with any mainstream view of proper statutory interpretation.

Employer attempts to evade both state regulation and insurance risk by purchasing stop-loss insurance with low attachment points has elicited a somewhat different reaction; some courts and commentators suggest that courts should deny deemer clause protection to such plans. ${ }^{128}$ Although such a judicial approach would require courts to ignore ERISA's text, it arguably would be consistent with a "purposive" view of statutory interpretation $^{129}$ if EHBP use of stop-loss insurance undermines the legislative goals implicit in ERISA.

The problem with this approach is that the extensive use of stop-loss insurance by EHBPs does not undermine ERISA. This is not to say that EHBPs that purchase low-attachment point stop-loss coverage are not exploiting a loophole in ERISA's text-they clearly are. It is unlikely that

125. See, e.g., Pitsenberger, supra note 5; Strain \& Kinney, supra note 5.

126. See Metropolitan Life Ins. Co. v. Massachusetts, 471 U.S. 724, 747 (1985) (stating that by recognizing differential treatment received by members of insured and self-insured plans, the Court only recognizes a "distinction created by Congress").

127. See, e.g., Edward Alburo Morrissey, Deem and Deemer: ERISA Preemption Under the Deemer Clause as Applied to Employer Health Care Plans with Stop-Loss Insurance, 23 J. LEGIS. 307, 314 (1997); $c f$. Robert N. Covington, Amending ERISA's Preemption Scheme, KAN. J.L. \& PuB. POL'Y, Winter 1999, at 1 (suggesting the need to amend the statute); Mark Alan Edwards, Comment, Prolections for ERISA Self-Insured Employee Welfare Benefit Plan Participants: New Possibilities for State Action in the Event of Plan Failure, 1997 WIS. L. REV. 351, 368-69 (suggesting that "[ $\mathrm{t}]$ he most logical way to reform the preemption effects of a federal statute . . . is to amend the staute itself").

128. Brown v. Granatelli, 897 F.2d 1351, 1355 (5th Cir. 1990); Sebelius, supra note 110, at $11 \mathrm{n.9}$ (arguing that self-insured employers with low attachment point stop-loss insurance should not be considered "self-insured" and should be required to follow state mandates).

129. HenRY C. Black, HandboOK ON THE CONSTRUCTION AND INTERPRETATION OF THE LAWS $\$ 33$ (1911); RONALD B. BROWN \& SHARON J. BROWN, STATUTORY INTERPRETATION: THE SEARCH FOR LEGISLATIVE INTENT $\$ 4.5$ (2002). 
the members of Congress who enacted ERISA in 1974 anticipated that EHBPs would be able to avoid the indirect effects of state insurance regulation while avoiding most insurance risk and would do so in large numbers. But the Congressional purpose inherent in ERISA's savings and deemer clauses is not to prevent small employers from avoiding state mandates. Rather, the purpose of ERISA's complicated structure is to balance traditional state authority to regulate insurance with employers' interest in avoiding the burden of complying with conflicting state laws. ${ }^{130}$ In striking that balance, ERISA creates two categories of EHBPs-those that purchase third-party insurance for their employees and those that do not-and allows the EHBPs themselves to choose their category. By creatively identifying ways of making it less costly to choose one category rather than the other, EHBPs act consistently rather than inconsistently with ERISA structure.

\section{EXPLOITING THE SAVINGS CLAUSE LOOPHOLE}

As Part II explained, ERISA's text in no way suggests that whether an EHBP purchases stop-loss insurance has any relevance to the question of whether the terms of health care coverage it provides its members are subject to state regulation, regardless of whether the attachment point of the stop-loss coverage is high or low. Additionally, there is no justification for courts to ignore ERISA's text in an effort to vindicate its purpose, because employers' use of stop-loss insurance does not undermine ERISA's attempt to balance competing policy goals. These conclusions do not suggest, however, that proponents of greater state regulation of health insurance must concede that they have been outmaneuvered by crafty employers. Just as the deemer clause creates a loophole that employers can exploit in an effort to minimize the reach of state regulation, the savings clause creates a loophole that states may exploit in an effort to maximize their regulatory reach.

ERISA permits EHBPs to arrange their business affairs in such a way that maximizes the benefits of self-insuring relative to purchasing thirdparty insurance. But ERISA also permits states to use their authority under the savings clause to maximize the benefits to EHBPs of purchasing thirdparty insurance relative to self-insuring. If states are unhappy that EHBPs use stop-loss insurance to make self-insuring a relatively more attractive option than purchasing state-regulated third-party insurance, their best

130. See, e.g., Ingersoll-Rand, 498 U.S. at 142 (describing ERISA's intent to minimize burdens on employers of conflicting state regulations). 
response is to regulate stop-loss insurers in a way that undermines that advantage.

To date, some states have attempted to exploit this loophole, but their success has been limited in two ways. First, the Second Circuit's decision in Travelers Insurance Co. v. Cuomo ${ }^{131}$ and the Fourth Circuit's decision in American Medical Security v. Bartlett ${ }^{132}$ invalidated two states' attempts to exploit this loophole, casting doubt on its legality. Both cases were incorrectly decided when issued, however, and the Supreme Court's recent opinion in Kentucky Ass'n further undermines them. Therefore, those decisions should not deter states-certainly those outside of the Second and Fourth Circuits-from taking advantage of the loophole. Second, since no state has yet exploited the loophole as fully as is possible, its full effect has never been tested. This Part describes the savings clause loophole, analyzes its legal status, explains how states can expand it, and considers the policy consequences of doing so.

\section{A. Exploiting the Loophole with Minimum Attachment Points}

In 1995, the National Association of Insurance Commissioners (NAIC) enacted a model statute requiring that stop-loss insurance policies sold to EHBPs to protect against excessive health care expenses include minimum attachment point levels. ${ }^{133}$ The NAIC model calls for specific attachment points to be a minimum of $\$ 20,000$, and minimum aggregate attachment points to be 110 to 120 percent of the EHBP's expected annual claims, depending on the size of the EHBP covered. ${ }^{134}$ Currently, at least fifteen states have adopted statutes or promulgated administrative regulations along the lines of the NAIC model. ${ }^{135}$ The purpose of such state regulations

131. 14 F.3d 708 (2d Cir. 1993), rev'd in part by N.Y. State Conference of Blue Cross \& Blue Shield Plans v. Travelers Ins. Co., 514 U.S. 645 (1995).

132. 111 F.3d 358 (4th Cir. 1997).

133. STOP LOSS INS. ACT (Nat'l Ass'n of Ins. Comm'rs 2004).

134. Id.

135. State statutes follow the structure of the NAIC model, although they sometimes change the aggregate and specific attachment points. See ALASKa STAT. $§ 21.42 .145$ (2004) (requiring stop-loss policies in Alaska to have at minimum a specific attachment point of $\$ 10,000$ and an aggregate attachment point for small employers of the greatest of $\$ 4000$ times the number of individuals, $120 \%$ of expected claims, or $\$ 20,000)$; GA. CODE. ANN. $\$$ 33-50-5 (2002) (giving the Georgia Insurance Commissioner ability to review stop-loss policies); Colo. REV. STAT. $§ 10-16-119$ (2002) (requiring a $\$ 15,000$ minimum specific attachment point and $120 \%$ minimum aggregate attachment point for policies issued in or after 2003); MINN. STAT. \$ 60A.235 (2002) (requiring stop-loss policies in Minnesota to have 
is no secret. As the Maryland Insurance Commissioner explained when initially promulgating that state's regulation, the goal of such rules is to prevent EHBPs from substituting stop-loss coverage for third-party health insurance in order to avoid the costs of state mandated benefits and other regulations while continuing to shift the insurance risk of employee illness to third parties. ${ }^{136}$

The deemer clause clearly prevents states from regulating EHBPs, but the savings clause just as clearly allows states to regulate insurance as long as the regulations do not extend to EHBPs. Stop-loss coverage providers, like health insurers, are in the business of insurance. If states may regulate the terms and conditions of health insurance policies, as Metropolitan Life clearly established that they can, states may also regulate the terms and conditions of stop-loss policies. When states require health insurance policies to include specific benefits, the option of purchasing third-party health insurance becomes less attractive to some EHBPs relative to the option of self-insuring. When states require stop-loss policies to include minimum attachment points, the option of purchasing third-party health insurance becomes more attractive to some EHBPs relative to the option of self-insuring. The fact that the savings clause gives states a tool to encourage EHBPs to purchase third-party insurance is no doubt an

a minimum specific attachment point of $\$ 10,000$ and a minimum aggregate attachment point higher than the sum of $140 \%$ of the first $\$ 50,000$ of expected claims, $120 \%$ of the next $\$ 450,000$ of expected claims, and $110 \%$ of the remaining expected claims); N.J. STAT. ANN. $\$ 17 \mathrm{~B}: 27 \mathrm{~A}-17$ (West 2003) (requiring stop-loss policies in New Jersey to have a minimum specific attachment point of $\$ 25,000$ and a minimum aggregate attachment point of $125 \%$ of expected claims); OR. REV. STAT. $\$ 742.065$ (2001) (requiring stop-loss policies in Oregon to have a minimum specific attachment point of $\$ 10,000$ and a minimum aggregate attachment point of $120 \%$ of expected claims); 191 IOWA ADMIN. CODE $\S$ $35.20(2)(\mathrm{g})$ (requiring stop-loss policies in Iowa to have minimum aggregate coverage at $125 \%$ of actuarially projected claims); NEv. ADMIN. CODE ch. 689B $\S 350$ (2003) (requiring stop-loss policies in Nevada to have a minimum specific attachment point of $\$ 10,000$; a minimum aggregate attachment point for groups not more than fifty people that is lower than the greater of $\$ 4000$ times the number of group members, $120 \%$ of expected claims, or $\$ 10,000$; for groups of more than fifty people an aggregate attachment point not lower than $110 \%$ of expected claims); 31 PA. CODE $\$ 89.472$ (2003) (requiring stop-loss policies in Pennsylvania to have a minimum specific attachment point of $\$ 10,000$ and a minimum aggregate attachment point of $\$ 100,000$ ).

136. See Am. Med. Sec., 111 F.3d at 362; see also Van Enters. v. Avemco Ins. Co., 231 F. Supp. 2d 1071, 1084 (D. Kan. 2002) (citing a bulletin issued by the Kansas Insurance Commissioner describing a desire to regulate stop-loss insurance because some "self-funded arrangements [we] re being formed for the purpose of avoiding compliance with Kansas' recent health insurance reform legislation"). 
unintended consequence of ERISA's structure. But then, so is the fact that the deemer clause allows EHBPs to use self-insurance coupled with lowattachment point stop-loss coverage to avoid the costs of state mandates without retaining any real insurance risk.

\section{B. The Loophole Closed? Two Circuits Invalidate Stop-Loss Regulations}

\section{Travelers Insurance Co. v. Cuomo}

In 1993, the Second Circuit considered challenges to a New York statute imposing hospital rate surcharges that differed based on the identity of the payer of hospital charges and to a New York Insurance Department regulation of stop-loss insurance contracts. ${ }^{137}$ The court held that ERISA preempted both the surcharges and the stop-loss regulations. ${ }^{138}$ The Supreme Court granted certiorari on the question of whether the surcharges were preempted ${ }^{139}$ and then, in a landmark decision that narrowed the scope of ERISA's "relates to" clause, reversed. ${ }^{140}$ The Court left unreviewed, however, the portion of the Second Circuit's opinion concerning stop-loss insurance regulation.

The stop-loss regulation at issue required stop-loss insurers to "undertake to ensure that statutorily mandated benefits be covered" by the underlying EHBP. ${ }^{141}$ The Travelers court held that the regulation related to employee benefit plans and was not protected by the savings clause because it did not qualify as an insurance regulation. The court's analysis, in relevant part, consisted of the following points: (1) the provision was "not limited just to the stop-loss layer of insurance but appl[ied] generally to the entire" EHBP; and (2) the regulation did "not have the effect of transferring or spreading risk between a self-funded plan and its stop-loss insurer." ${ }^{\text {142 }}$ Although both descriptions are fair characterizations of the New York regulation's effects, neither supports the conclusion that the provision does not constitute an "insurance regulation" protected by the savings clause. Any law governing to whom and under what conditions an

137. Travelers, $14 \mathrm{~F} .3 \mathrm{~d}$ at 711.

138. $I d$.

139. N.Y. State Conference of Blue Cross \& Blue Shield Plans v. Travelers Ins. Co., 514 U.S. 645,654 (1995).

140. Id. For a detailed analysis of the Supreme Court's decision and its effect the jurisprudence of ERISA's “relates to" clause, see Korobkin, supra note 27, at 488-90.

141. Travelers, 14 F.3d at 724.

142. Id. 
insurance company may sell insurance products to customers constitutes a "regulation of insurance" under any common-sense understanding of that term.

The Supreme Court's decision last term in Kentucky Ass' $n$ jettisoned the Court's prior complicated test for whether a state law constitutes an insurance regulation for savings clause purposes, replacing it with a simpler approach consistent with this view. In so doing, it severely undermined the Second Circuit's holding in Travelers. Recall that under the rule of Kentucky Ass'n, a state law qualifies for protection from ERISA preemption under the savings clause so long as the law is "specifically directed" at the insurance industry and it regulates insurance practices. ${ }^{13}$ The New York regulation clearly satisfied both prongs of this test, as the following paragraphs explain.

In Kentucky Ass'n, petitioner health insurance companies argued that a state "any willing provider" (AWP) law preventing insurers from excluding health care providers from their networks was not specifically directed at insurers because it equally affected providers. ${ }^{144}$ Disposing of this argument, the Court first observed that, by its terms, the statute imposed requirements only on insurers. ${ }^{145}$ It then explained that the fact that a regulation of insurance entities has the consequence of affecting the choices available to other entities does not preclude savings clause protection for the regulation. ${ }^{146}$ Like the Kentucky AWP law, the New York regulation at issue in Travelers was specifically directed only at insurance companies (specifically, those that sell stop-loss insurance policies). By essentially forbidding insurance companies from selling policies to EHBPs that do not provide the full range of benefits that the state mandates of health insurers, the regulation certainly affected the range of contracting options available to New York EHBPs, but not in a qualitatively different way than the Kentucky Ass'n AWP law impacted the range of contracting options available to Kentucky doctors. More to the point, all insurance regulations affect the market choices available to third parties who wish to contract with insurance companies; ${ }^{147}$ the New York stop-loss regulation was

143. Kentucky Ass'n of Health Plans v. Miller, 123 S. Ct. 1471, 1475 (2003); see also supra Subsection I.B.3.

144. Kentucky Ass'n, 123 S. Ct. at 1475.

145. Id.

146. Id. at $1475-76$.

147. Id. at 1476 ("Regulations 'directed toward' certain entities will almost always disable other entities from doing, with the regulated entities, what the regulations forbid; this does not suffice to place such regulation outside the scope of ERISA's savings clause."). 
a quite ordinary insurance regulation in this respect.

The Kentucky Ass'n petitioners also argued that the AWP laws at issue did not regulate the insurance practices of insurance companies because those laws did not directly affect the allocation of risk between insurers and insured members. ${ }^{148}$ Rejecting this argument, the Court explained that the laws affected insurance practices by limiting the "scope of permissible bargains" between insurers and potential customers, as contrasted with a regulation governing how much insurance companies must pay janitors to clean their offices, which would be directed at insurance companies but have nothing to do with the insurance function. ${ }^{149}$ Similarly, the New York stop-loss regulation is directed at insurance companies qua insurance companies, rather than insurance companies qua purchasers of office supplies, insurance companies qua landlords, or insurance companies acting in some other role unrelated to the provision of insurance.

\section{American Medical Security, Inc. v. Bartlett}

In 1995, the Maryland Insurance Commissioner promulgated a regulation providing that an insurance product sold to an employer that insures against the cost of claims that result from employees' sickness or accidents would be characterized as "stop-loss insurance" only if it has a minimum specific attachment point of $\$ 20,000$ and a minimum aggregate attachment point of at least $125 \%$ of the expected annual claims cost. ${ }^{150} \mathrm{~A}$ group of employers with self-funded EHBPs sought an injunction against Maryland's enforcement of the regulation, ${ }^{151}$ and the regulation became the test case for whether states possessed the power to exploit ERISA's savings clause loophole.

In American Medical Security, Inc. v. Bartlett, ${ }^{152}$ the Fourth Circuit upheld a district court ruling that ERISA preempted the regulation on the ground that it "attempt [ed] to mandate benefits that certain self-insured plans may offer." American Medical Security remains today the leading federal court

148. Id. at 1477 .

149. Id.

150. MD. Regs. CoDE tit. $9 \$ 31.02$ (1995), repealed by Am. Med. Sec., Inc., v. Barlett. 111 F.3d 358 (4th Cir. 1997). In a subsequent revision of the regulation, Insurance Commissioner changed the minimum specific attachment point for stop-loss insurance to $\$ 10,000$ and the minimum aggregate attachment point to $115 \%$ of expected claims costs. 23 Md. Reg. Issue 2, Jan. 19, 1996.

151. Am. Med. Sec., 111 F.3d at 360-61.

152. 111 F.3d 358.

153. Id. at 365 . 
decision on the subject of state attempts to regulate stop-loss insurance for the purpose of making self-insuring a less attractive option for EHBPs. ${ }^{154}$ This is unfortunate because the opinion is badly flawed. At the time it was issued it was inconsistent with ERISA's text and structure as well as existing Supreme Court decisions interpreting the statute. In addition, the Supreme Court's Kentucky Ass'n decision now provides further support for the contention that American Medical Security was wrongly decided.

Maryland's attempt to exploit the savings clause made for a bad test case from the start because that state's regulation was at best poorly drafted and at worst substantively incoherent. Rather than establishing minimum attachment points for stop-loss insurance, effectively prohibiting the sale of stop-loss insurance with lower attachment points, as the NAIC model statute does, the Maryland regulation provided that an insurance policy with a low attachment point that protected an EHBP against losses resulting from employee health care costs would be "considered to be a policy or contract of health insurance."

The most natural reading of this regulation is that low-attachmentpoint stop-loss policies would be required to provide coverage for statemandated health care benefits. ${ }^{156}$ The problem with such a requirement is that it is logically incoherent to require a stop-loss insurer to cover mandated health benefits because a stop-loss insurer's customersEHBPs-need not provide state-mandated benefits to plan members in the

154. Although American Medical Security postdates the Second Circuit's decision in Travelers, the Travelers decision has been largely overlooked by commentators, most likely because the majority of that opinion-but not the portion relevant to this discussion-was subsequently reversed by the Supreme Court. Only Travelers and American Medical Security have addressed state attempts to exploit the savings clause loophole on the merits. The issue has been raised in a handful of other cases, but these other courts have resolved their cases on procedural grounds without opining on the substantive question. See, e.g., Associated Indus. of Mo. v. Angoff, 937 S.W.2d 277, $284-85$ (Mo. Ct. App. 1996) (overruling Mo. CODE REgS. ANN. tit. $20 \S 400-2.150$, a regulation of stop-loss insurance, because the insurance commissioner needed statutory authority or actuarial data to set the minimum attachment point for stop-loss insurance); Van Enter., Inc. v. Avemco Ins. Co., 231 F. Supp. 2d 1071, 1087-88 (D. Kan. 2002) (overruling a decision by the insurance commissioner to place minimum aggregate and specific attachment points on stop-loss insurance because he did not have statutory authority to do so).

155. MD. CODE REGS. ANN. tit. 9 \$ 31.02.

156. Cf. Brown v. Granatelli, 897 F.2d 1351, 1356-58 (5th Cir. 1990) (Brown, J., dissenting) (arguing that a stop-loss policy covering an EHBP is in fact a group health insurance policy under Texas law and therefore required to provide state health benefits mandates). 
first instance. Consider, for example, a Maryland mandate that health insurers provide coverage for skilled nursing home facilities. ${ }^{157}$ What would it mean for Maryland to require an insurance policy issued to an $E H B P$ to include such coverage? Arguably, this requirement could be interpreted as preventing the stop-loss insurer from excluding the EHBP's costs of providing skilled nursing care to its members from its calculation of whether an EHBP's losses have reached the policy's attachment point. Such an interpretation would be unobjectionable but mostly beside the point, because the insurance commissioner's concern in enacting the regulation was with EHBPs that do not provide skilled nursing home benefits, not with stop-loss carriers that refuse to reimburse EHBPs for the costs of nursing home care. If an EHBP excludes skilled nursing home care from the benefits it promises to its members, a stop-loss insurance company will never find itself obligated to pay costs incurred as a result of plan members receiving skilled nursing home care. Because the EHBP does not pay nursing home costs, the fact that a plan member incurs such costs will never result in the EHBP making a claim against its stop-loss insurance policy. A variation of this understanding of the regulation is that it requires a stop-loss insurer to reimburse employees directly for skilled nursing home costs that the employees incur. This interpretation makes little sense either, because stop-loss insurers have no contractual obligations of any kind to employees.

A less natural, but still plausible, interpretation of the Maryland regulation is that by labeling certain stop-loss insurance policies "health insurance," the state would consider the EHBP purchasers of those policies to be "insured" rather than "self-insured" plans for ERISA purposes and therefore required to provide all state-mandated benefits to their members.

The problems with the Fourth Circuit's decision in American Medical Security begin with its failure to make clear which of these readings (i.e., stop-loss insurers must pay for mandated benefits or EHBPs that purchase stop-loss insurance must provide mandated benefits) it gave to the regulation under scrutiny. At one point the court "recognize[s] that the regulations are carefully drafted to focus directly on insurance companies issuing stop-loss insurance and not on the [EHBPs] themselves."158 This statement implies the former construction. In the very next paragraph, however, the court asserts that the regulation "seek[s] to require self-

157. MD. Code ANN., INS. $\$ 15-801$ (2003).

158. Am. Med. Sec., 111 F.3d at 363. 
funded plans to offer coverage consistent with state insurance law. ${ }^{159}$ This statement implies the latter interpretation.

Which of these two statements reflects the court's interpretation of the regulation is critical. If the Maryland regulation is interpreted to mandate that self-funded EHBPs with low-attachment-point stop-loss coverage provide specific benefits to their members, then the rule clearly would be preempted, but the court's opinion would be of trivial importance because it merely follows well-established deemer-clause precedent-states may not regulate EHBPs as if they are insurance companies, even if they serve an insurance function. ${ }^{160}$ If the Maryland regulation places requirements only on stop-loss insurance companies, as it appears to according to its text, however, the resolution of the case takes on a great deal of importance. This court's confusion is understandable in light of the regulation's incoherence, but it makes it quite difficult to divine the court's holding in the case.

The court's failure to clearly state its interpretation of what the regulation at issue actually requires suggests a lack of understanding on its part that its precise resolution of this question is important to the case. The best explanation of why American Medical Security explains the court's understanding of the Maryland regulation so poorly is that the court determined that ERISA preempts the regulation regardless of its precise meaning. The court's opinion repeatedly emphasizes that the Maryland regulation had the "purpose and effect" of influencing the behavior of selffunded plans. ${ }^{161}$ It asserts that the deemer clause prohibits Maryland law from "aiming at the plan-participant relationship." ${ }^{162}$ It also concludes that such purpose and effect calls into doubt whether the savings clause protects Maryland regulation because it arguably fails the Supreme Court's savings clause requirements of being a state law directed at the insurance industry and being integral to the insured-insurer relationship. ${ }^{163}$ Thus, the court appears to believe that ERISA's deemer clause, and perhaps also its savings clause, prohibit state regulations enacted with the intent or effect of increasing the attractiveness to EHBP's of purchasing third party health insurance for their members, regardless of whether the state directly regulates

159. Id. at $363-64$.

160. See supra Section II.C.

161. Am. Med. Sec., 111 F.3d at 363.

162. Id. at 364 .

163. Id. at 363 ("[T] he complications of the second and third Metropolitan Life factors [concerning the savings clause] together with the 'deemer clause' provide the core difficulty with the state's regulation of stop-loss insurance policies issued to ERISA plans."). 
what choices EHBPs must make or, alternatively, regulates the products third-party insurance companies may sell.

There is no text or precedent that supports this interpretation of ERISA. States' power to regulate under the savings clause is limited only by the deemer clause's prohibition against applying insurance regulations to EHBPs themselves. American Medical Security's conclusion that it is "impermissibl[e]" for state regulations to affect ERISA plans' "costs and choices" finds no support in ERISA's language and is inconsistent with the statute's structure, ${ }^{164}$ which allows for the preemption of a state law that "relates to" EHBPs and then the saving of that same law as an insurance regulation. The court's sweeping statement effectively reads the savings clause out of the statute. The court's conclusion also is inconsistent with the Supreme Court's ruling in Metropolitan Life. State benefits mandates increase the costs associated with purchasing health insurance for EHBPs and limit the choices available in the insurance market. Stop-loss insurance regulations merely have similar effects on an EHBP's decision to selfinsure.

The Fourth Circuit's analysis begins to go awry when it asserts that "state insurance regulation may not directly or indirectly regulate selffunded ERISA plans" ${ }^{165}$ - a statement of the law that is, at best, misleading. As explained above, whether an EHBP is insured or self-insured is not the operative question under ERISA. The statute prohibits states from directly regulating EHBPs, whether they purchase third-party insurance or not. But a state regulation of insurance may indirectly affect options available to EHBPs, and it may therefore make self-insurance more or less attractive to EHBPs. If a state law having such an effect is considered an "indirect regulation," then the Fourth Circuit's statement of the law is incorrect.

As authority for its "directly or indirectly" statement, American Medical Security cites to the Supreme Court's decision in FMC Corp. ${ }^{166}$ but the relevant passage in FMC Corp. is actually itself a quotation from the Supreme Court's earlier opinion in Metropolitan Life. In the original statement, the Court said: "We are aware that our decision [upholding a mental health mandate as applied to third-party insurance companies] results in a distinction between insured and [self-insured] plans, leaving the former open to indirect regulation while the latter are not." ${ }^{167}$ This

164. Id. at 364 .

165. Id. at 361 .

166. Id. (citing FMC Corp. v. Holliday, 498 U.S. 52, 62 (1990)).

167. Metropolitan Life Ins. Co. v. Massachusetts, 471 U.S. 724, 747 (1985), quoted in FMC Copp., 498 U.S. at 62. 
sentence recognizes that an EHBP that purchases third-party health insurance for its employees is indirectly subject to benefits mandates (because it cannot buy insurance that does not include the specified benefits), whereas an EHBP that self-insures its employees' health care costs is not affected at all-indirectly or otherwise-by the state law. The mere observation that state benefits mandates do not have even an indirect effect on self-insured EHBPs does not logically imply that other types of state insurance regulations that do have an indirect effect on self-insured EHBPs are therefore prohibited, as it would have to for Metropolitan Life to support the Fourth Circuit's conclusion in American Medical Security. In fact, Metropolitan Life suggests exactly the opposite: A state's direct regulation of insurance may permissibly have the effect of skewing the cost benefit analysis of an EHBP deciding whether to self-insure its members' health care costs or purchase third-party health insurance policies for that purpose.

Although the American Medical Security court's decision finds no support in ERISA's language or in the relevant Supreme Court decisions on related issues, the court's decision could be defensible nonetheless if the specific type of state law in question undermines ERISA's intent. ${ }^{168}$ The problem is that the argument that states should be prohibited from regulating stop-loss insurance in a way that makes self-insurance less attractive to EHBPs runs into precisely the same trouble as does the argument that EHBPs should be prohibited from using stop-loss insurance with low attachment points to make self-insurance more appealing. ${ }^{169}$ ERISA balances the value of allowing states to regulate insurance with the value of allowing employers to avoid inconsistent state laws. To effectuate this balance, Congress gave states the right to regulate insurance companies under the savings clause and gave EHBPs a safe harbor under the deemer clause to avoid such regulation by not purchasing third-party insurance. Congress did not intend for ERISA to make it particularly easy or cost-free for EHBPs to opt to finance their member benefits without third-party insurance any more than it intended to make self-insuring particularly burdensome. State attempts to use stop-loss insurance regulation to make self-insurance less attractive to EHBPs exploit a loophole, but such exploitation-like EHBPs exploitation of the deemer clause loophole-is consistent, rather than inconsistent, with ERISA's structure.

Immediately after losing in the Fourth Circuit, Maryland enacted

168. BROWN \& BROWN, supra note 129, § 2.1; DICKERSON, supra note 129, at 67-102.

169. See supra Section II.C. 
legislation with the identical purpose to the regulation that was struck down ${ }^{170}$ but with language that followed the NAIC's Model Rule and avoided the confusion surrounding the regulation's definition of some stop-loss policies as health insurance. ${ }^{171}$ The statute prohibited insurance companies from selling stop-loss policies with specific attachment points lower than $\$ 10,000$ or aggregate attachment points lower than $115 \%$ of expected annual claims. ${ }^{172}$ American Medical Security claimed that the new statute was substantively no different than the regulation prohibited by the Fourth Circuit; ${ }^{178}$ the Maryland Insurance Commissioner claimed that the statute was protected from preemption by the savings clause. ${ }^{174}$ Both sides were correct.

American Medical Security asked a federal district court to enjoin enforcement of the statute, but the court ruled that since the statute was newly enacted, the insurance companies would have to proceed with a new challenge on the merits. ${ }^{175}$ The company initially promised a new court fight on the ground of ERISA preemption, ${ }^{176}$ but it later chose instead to withdraw from the Maryland insurance market and drop its challenge. ${ }^{177}$ The company's general counsel said he was "not sure if anyone will want to put the money behind a challenge to the law." 178 To date, no one has.

ERISA is a complicated statute, to be sure, but the operation of the savings clause and the deemer clause are spelled out rather clearly: States may regulate the sale of insurance, but their insurance regulations may not extend to self-insured EHBPs that serve an insurance function vis-à-vis their members but are not otherwise in the insurance business. The flawed analysis of the Second and Fourth Circuits notwithstanding, this statutory

170. Maryland's Deputy Insurance Commissioner explained that the statute prevents insurance companies from selling stop-loss policies to self-insured employers that "are really a sham to avoid state regulations." Dennis Kelly, Maryland Has Begun Enforcing, BESTWIRE, July 26, 1999 (quoting Deputy Insurance Commissioner Dennis Carroll); see also Maryland Regulators Enforcing Law on Stop-Loss Attachments, Bus. INS., July 26, 1999, at 1.

171. MD. CODE ANN., INS. § 15-129 (1999).

172. Id.

173. See Jerry Geisel, Stop-Loss Enforcement OK'd: But Maryland Likely to Face Additional Legal Challenges, Bus. INS., Sept. 6, 1999, at 2.

174. See id.

175. See id.

176. See id.

177. See Jerry Geisel, Stop-Loss Battle To End: Insurer To Withdraw from Maryland, Ending Challenge to Law, Bus. INS., Nov. 1, 1999, at 2.

178. Id. (quoting Tim Moore, General Counsel and Senior Vice President of American Medical Security). 
balance permits states to place limits on what types of stop-loss insurance products insurance companies may sell and to whom they may sell them.

\section{Further Exploiting the Savings Clause Loophole: "Underlying Coverage" Requirements}

Since the Second Circuit's decision in Travelers, all of the states that have attempted to exploit the savings clause loophole have employed what might be labeled a restrained approach. Specifically, those states have required only that stop-loss insurance have minimum attachment points so that EHBPs cannot seamlessly replace third-party health insurance with stop-loss insurance and avoid the costs of state benefits mandates and insurance taxes without sacrificing any of the benefits of third-party insurance. The reason for such regulatory restraint is understandable: Only EHBPs that purchase stop-loss insurance with very low-attachment points are purchasing such insurance for the obvious purpose of exploiting the deemer clause loophole and dodging the cost of state law requirements. If states wish to use the savings clause loophole to neutralize the deemer clause loophole, focusing only on low-attachment point stoploss insurance is appropriate.

Mandating minimum attachment points for stop-loss insurance is a restrained regulatory approach because, although it makes the decision to self-insure (and thereby avoid state health insurance mandates) less desirable from the perspective of EHBPs, it makes that decision only marginally less desirable. With such stop-loss insurance regulations enacted, an EHBP that wishes to avoid the costs of state insurance mandates must maintain some insurance risk, but it is still able to cede most of the insurance risk to a third-party by purchasing stop-loss insurance with the minimum permissible attachment points. Given this set of choices, some EHBPs that would choose to self-insure and purchase stop-loss insurance with very low attachment points are likely to decide to purchase third-party health insurance instead, but many would choose to purchase stop-loss insurance with higher attachment points and continue to avoid the consequences of state insurance regulations, including benefits mandates and premium taxes.

The minimum attachment point approach to regulation fails to recognize that the savings clause loophole can be exploited to far greater effect. Specifically, following the New York regulation improperly struck down in Travelers, states could enact legislation or promulgate regulations that prohibit insurance companies from selling any stop-loss coverage for 
losses associated with health care costs unless the underlying coverage provided by the EHBP to its employee members includes all of the statemandated benefits that insurance companies must provide. Such laws might be called "underlying coverage requirements" for stop-loss insurance.

Much like minimum attachment point requirements, underlying coverage requirements would be directed at the insurance practices of insurance companies and should be protected from preemption under the savings clause on that basis. It is true that such requirements would have the indirect effect of preventing other entities (here, EHBPs) from doing in concert with an insurance company what the law prohibits insurance companies from doing. This fact, however, does not vitiate savings clause protection for the restriction placed on insurance companies. ${ }^{179}$ And because such a law would not place any requirements on EHBPs, it would not interfere with the safe harbor provided by the deemer clause. ${ }^{180}$

An underlying coverage requirement would render the option of selfinsuring members' health care costs far less attractive to EHBPs that currently self-insure their members' medical costs, purchase stop-loss insurance to reduce insurance risk, and provide their members a menu of benefits that does not include all state mandated coverage. Such EHBPs would have to choose between (1) maintaining their stop-loss insurance and expanding the benefits they provide to their members to include all state-mandated benefits, (2) purchasing third-party health insurance for their members that includes all state-mandated benefits, or (3) functionally self-insuring their employees' medical costs by retaining the entire insurance risk. There is little doubt that many EHBPs that currently self-insure and offer a limited set of benefits to their members would choose either the first or the second option, especially if they do not have extremely large risk pools. In other words, a likely consequence of a state instituting an underlying coverage requirement would be that employees who enjoy health care coverage and work for all but the largest employers would receive the benefits mandated by the state. Such a result would be consistent with the expectations of ERISA's drafters, who envisioned that the type of large employers that operate in multiple states could develop a single EHBP for all of their employees free from inconsistent state regulations, but that states would otherwise continue to regulate health insurance. ${ }^{181}$

179. See Kentucky Ass'n of Health Plans v. Miller, 123 S. Ct. 1471, 1475 (2003).

180. See FMC Corp. v. Holliday, 498 U.S. 52, 61-64 (1990).

181. See generally GAO, Issues AND TRENDS, supra note 102. 


\section{Drawbacks to Exploiting the Savings Clause Loophole}

From the perspective of state regulators, there are three primary drawbacks to exploiting the savings clause loophole, which vary in their nature and severity: (1) some employers might end their sponsorship of EHBPs; (2) employers operating in multiple jurisdictions might be able to escape the impact of the state's efforts; and (3) financially precarious employers might drop stop-loss insurance coverage, increasing their insolvency risk. Each of these drawbacks affects both the minimum attachment point and the underlying coverage requirement regulatory approach, although each is likely to have a more significant impact on underlying coverage requirements. The first drawback should not be a significant concern in light of policy choices already made by the state; the second should also not be a significant concern because it could reduce the effectiveness of attempts to exploit the loophole but would not have independently undesirable consequences; the third should give regulators significant pause, especially in the case of underlying coverage requirements.

\section{Loss of Benefits}

The first drawback to exploiting the savings clause loophole is that doing so runs the risk of causing some employers that currently sponsor EHBPs to stop providing any health care coverage to their employees. No federal or state law (with the exception of Hawaii) requires employers to provide health care coverage as a fringe benefit; ${ }^{182}$ thirty-four percent of the nation's employers-and forty-five percent of employers with fewer than nine workers-do not. ${ }^{183}$ The cost of mandates varies from state to state, of course, but few doubt that they are substantial, and some estimates suggest they can account for up to nearly one-fourth of health care claims

182. Hawaii law mandates employer-provided health coverage, see HAW. REV. STAT. $§ 393$ (2004), but the state received an exception from the federal government for its law. See 29 U.S.C. 1144 (2000). A recently enacted California statute would have mandated that employers with more than fifty employees provide health care coverage or pay into a state pool to fund the cost of providing such coverage. Health Insurance Act of 2003, CA. LAB. CODE $§ \S 2120-2210$ (West Supp. 2004). California voters blocked the law's implementation, however, by defeating a ballot proposition in November 2004. Jordan Rau \& Evan Halper, Election 2004, L.A. Times, Nov. 4, 2004, at B1. Whether the measure would have survived ERISA preemption analysis is unclear.

183. KFF/HRET, supra note 93, at 40. 
costs. ${ }^{184}$ State insurance premium taxes also increase the cost to employers of providing third-party insurance for their employees. Faced with a choice between providing more expensive health care coverage through the purchase of third-party insurance, continuing to self-insure but doing so without the safety-net of stop-loss insurance or with higher-attachmentpoint stop-loss insurance, or simply dropping health care coverage from their menu of fringe benefits entirely, some employers will-and many might-select the last option. The ironic effect could be that the very employees state regulators desire to protect could be left worse off.

This concern, however, is one that is broader than the issue of employers who self-insure in order to avoid state benefits mandates or premium taxes. State regulators face the same risk when they decide to impose any mandate or tax on the state's insurance companies. ${ }^{185}$ Each mandate or tax increases the cost to employers of providing third-party health insurance, thus increasing the risk of marginal employers dropping their sponsorship of health insurance. By one estimate, one-fifth of small employers that do not currently offer health care benefits to their employees would do so if there were no benefits mandates. ${ }^{186}$

A state that mandates that health insurance companies provide specific benefits presumably has already decided that the gains to employees whose employers provide increased coverage to meet the minimum requirements outweigh the costs to employees whose employers elect to eliminate health care coverage altogether. Having already accepted this trade-off, it is not clear why a state would hesitate to impose an underlying coverage mandate on stop-loss insurance companies (except, perhaps, if the state accepted the risks associated with imposing benefits mandates only as a result of its knowledge that cost-conscious employers could avoid those mandates without dropping coverage by becoming self-insured and purchasing stoploss coverage). Put another way, if a state fears that imposing an underlying coverage mandate will cause many employers to cancel their EHBPs, it

184. According to a GAO study, Virginia's mandated benefits account for twelve percent of group health insurance claims, Maryland mandated benefits account for twenty-two percent of claims, and Iowa mandated benefits only account for only five percent of claims. U.S. Gen. Accounting Office, GAO/HEHS-96-161, Health Insurance Regulation: VARYING STATE REQUIREMENTS AFFECT COST OF INSURANCE 11 (1996).

185. They face a similar concern when they decide whether to raise the state minimum wage, knowing that some employers might lay-off low-wage employees rather than increase wages to comply with the new minimum. Robert A. Hillman, The Rhetoric of Legal Backfire, 43 B.C. L. REv. 819, 852 (2002); Daniel Shaviro, The Minimum Wage, the Eamed Income Tax Credit, and Optimal Subsidy Policy, 64 U. CHI. L. ReV. 405 (1997).

186. See Jensen, supra note 42. 
should reconsider the efficacy of its benefits mandates.

\section{Jurisdiction Jumping}

A second drawback to regulating stop-loss insurance providers is that, to the extent that only some states choose to enact such regulations, they might be relatively easy for EHBPs of some multi-state employers to avoid.

States' authority to regulate insurance allows them to set the terms and conditions of insurance policies issued in their state. A typical state statute prohibits any person from transacting "a business of insurance in" or "relative to a subject of insurance resident, located or to be performed in" the state without complying with applicable provisions of state law. ${ }^{187}$ Thus, State A can require that insurance companies that sell health insurance policies covering employees residing in that state comply with applicable state requirements. ${ }^{188}$ But State A lacks authority over the terms and conditions of policies an insurer sells to customers that reside in State B. ${ }^{189}$ If an employer's entire business operation is located in State B, State A should have little concern with the terms of a stop-loss insurance policy that the employer purchases. Difficult questions arise, however, when an employer's business operates in multiple states. An employer with headquarters in State A, its major plant in State B, and employees spread out over States A, B, C, D, might respond to the imposition of an underlying coverage mandate on stop-loss insurers in State $A$ by purchasing its stop-loss policy in State B from a company duly licensed there. It is unclear whether, and in what precise cases, State A could assert regulatory authority over the terms and conditions of the stop-loss policy under these circumstances-complicated choice of law questions are involved. ${ }^{190}$

187. See, e.g., ARIz. REv. STAT. § 20-107 (2004); Fla. Stat. ch. 624.11 (2004); IdAHo Code $\S$ 41-113 (2004); NeV. Rev. STAT. 679A.150 (2004); WYo. STAT. ANN. § 26-1-103 (2004).

188. See Guardian Life Co. of Am. v. Ins. Comm'r, 446 A.2d 1140 (Md. App. 1982) (holding that a group health insurance policy sold by a Rhode Island insurance company to a Maryland employer and covering Maryland employees must comply with Maryland insurance requirements notwithstanding that the master policy was delivered by the insurance company to a Rhode Island trustee rather than to the employer in Maryland).

189. Rizzo v. Price, 294 A.2d 541 (Conn. 1972); Standard Ins. Co. v. Sturdevant, 566 P.2d 52 (Mont. 1977). For statutes, see ConN. GEN. STAT. \$§ 1-1, 38-69, 38-71, $38-72$ (2003); MASS. GEN. LAWS ANN. ch. 175, § 162; (1999); and N.Y. INS. LAW § 2114, 2115 (a), 2116 (2004).

190. See generally Banks McDowell, Choice of Law in Insurance: Conflicts Methodology To Minimize Discrimination Among Policyholders, 23 CoNN. L. Rev. 117 (1990) (discussing the complex choice of law problems that arise when multiple states have an interest in the law 
The possibility that employers operating in multiple states might avoid the effects of stop-loss insurance in one of those states by contracting for stop-loss insurance in a different jurisdiction suggests that the savings clause loophole might be somewhat narrower than regulators wish it would be. But the possibility that exploiting the savings clause loophole might not be a complete response to all employers that exploit the deemer clause loophole does not logically provide an argument against regulators taking action. At the very least, minimum attachment point regulations and underlying coverage mandates would have their desired effect on employers whose operations are located in a single state, and employers with multiple-state operations best able to avoid the consequences of such regulations will tend to be larger employers less likely to use lowattachment-point stop-loss insurance for the sole purpose of avoiding state benefits mandates.

\section{Risk of Insolvency}

The third drawback to regulating stop-loss insurance is that some employers might choose to continue to operate a self-insured EHBP but without stop-loss coverage. This risk is especially great if the state institutes an underlying coverage requirement rather than merely a minimum attachment point. Self-funded employers without stop-loss insurance expose their employees to an increased risk of plan insolvency. ERISA imposes no federal financial solvency requirements on EHBPs, ${ }^{191}$ and the deemer clause prevents states from imposing any on them. A catastrophic medical expense incurred by a participant in a self-funded EHBP without stop-loss coverage could cause the plan to become insolvent, leaving plan members without coverage or increasing the financial burden on any statesponsored fund that might insure such insolvencies or provide health benefits to the uninsured. ${ }^{192}$ That the potential for self-insured EHBPs to

governing an insurance contract).

191. In contrast, ERISA does include detailed requirements for employer-sponsored pension plans to insure their solvency. Donald T. Bogan, Protecting Patient' Rights Despite ERISA: Will the Supreme Court Allow States To Regulate Managed Care?, 74 TuL. L. REv. 951, 975 (2000).

192. To cover members of an insured EHBP that becomes insolvent, states provide health guaranty associations. All states have enacted statutes based on an NAIC Model Law that requires insurance companies to join as a condition of transacting business in the state. The association is run by a board of directors, who determine the action necessary to cover individuals who lose health care coverage as a result of their company's insolvency. This action can range between assuming coverage for individuals from the guaranty fund to 
become insolvent is of concern to state regulators is demonstrated by the fact that all states have solvency requirements for insurance companies. ${ }^{193}$ This concern is also demonstrated by the fact that many states require selfinsured employee health benefit plans that are exempt from ERISA preemption for various reasons to purchase stop-loss insurance. ${ }^{194}$

Unlike the drawbacks of regulating stop-loss insurance described above, the increased risk of EHBP insolvency is an independent negative consequence of regulation that regulators must balance against the benefits of encouraging more employers to provide state mandated benefits as part of their self-insured plans or choosing to purchase thirdparty insurance subject to those state mandates.

\section{CONCLUSION}

For better or worse, ERISA creates a two-tiered structure for the regulation of employer-provided health insurance benefits. Employers who

dispersing the individuals between member insurance companies. LIFE AND HEALTH INS. GUARARTY ASs'N MODEL ACT (Nat'l Ass'n of Ins. Comm'rs 2003). For examples of relevant state regulations, see ARIz. REV. STAT. $\$ \S 20-681$ to 20-695 (2004); CAL. INS. CODE $\$ 1067.18$ (2004); COLO. REv. STAT. \$§ 10-20-101 to 10-12-120 (2004); 215 Ill. CoMP. STATS. 5/531-01 to 5/531-19 (2004); MD. CODE ANN., INS. \$§ 9-401 to 9-419 (2004); Mo. ReV. STAT \$§ 376.715- 376.758 (2004); N.Y. INS. LAWS $\$ 8701-7718$ (2004).

193. See, e.g., ALASKA ADMIN. CODE tit. 3, § 21.241 (2003) (placing limitations on the type of investments and the percentage of total investments that health insurers can place in those investments); id. $\$ 21.320$ (regulating the amount and type of reserves that insurance companies must retain); CONN. AGENCIES REgS. $\S 38 \mathrm{a}-214-4$ (2003) (requiring health insurers to retain a certain amount in contingency reserves); FLA. ADMIN CODE r. 4-137.001 (describing insurer reporting requirements); IOWA ADMIN. CODE r. 191-41.11(514B) (establishing minimum net worth for HMOs); MD. REGS. CODE tit. 31, $\$ 12.01$ (setting HMO fiscal requirements).

194. For example, Georgia, South Carolina, New Mexico, Minnesota, among others, require multiple-employer health benefits plans, which are exempt from ERISA's preemption protection against state laws, to buy stop-loss insurance. GA. COMP. R. \& REGS. $r$. 120-2-50-.05 (2003) ("[A] multiple employer self-insured health plan is required to obtain individual and aggregate stop-loss coverage from an insurer authorized to transact business in Georgia); MINN. R. 2765.1300 (2002) (requiring every joint self-insurance arrangement to carry both individual and aggregate stop-loss insurance); N.M. ADMIN. CODE tit. $13 \S$ 19.4.16 (2004) ("[E]very MEWA shall have at all times individual and aggregate excess stoploss coverage from an insurer authorized to transact insurance in the state of New Mexico."); S.C. CODE ANN. REgs. 69-42. Other states, Wisconsin, require local government units to obtain stop-loss insurance to cover their self-insured plans. WIS. ADMIN. CODE INS. 8.11 (2003). 
purchase third-party health insurance are indirectly subject to state regulation because the savings clause exempts state regulation of insurance companies from federal preemption. Employers who self-insure their EHBP are not subject to state level requirements, because the deemer clause prevents state regulators from treating EHBPs like insurance companies. This statutory structure, reinforced by recent Supreme Court rulings expanding the scope of the savings clause, provides an incentive for employers who wish to avoid state mandated benefits and premium taxes but who do not wish to bear insurance risk to self-insure their EHBPs and purchase low attachment point stop-loss insurance. This approach exploits a loophole in ERISA, but one that is unavoidable in light of the text of the deemer clause; it would be improper for courts to judicially close the loophole in the light of ERISA's text and structure.

The savings clause, however, provides regulators with a loophole of their own that they may exploit to reduce the desirability to employers of exploiting the deemer clause loophole. Properly interpreted, the savings clause gives states the right to prevent insurance companies from selling low attachment point stop-loss policies to EHBPs, or even from selling stoploss policies with any attachment point to EHBPs that do not provide statemandated benefits for health insurance programs in general. Rather than decrying the consequences of courts properly interpreting the deemer clause, regulators need to decide whether the benefits of exercising their power over stop-loss insurance providers granted by the savings clause outweigh the corresponding costs of doing so. One good loophole deserves another. 